\title{
TRABALHO E SINDICALISMO NO BRASIL: UM BALANÇO CRÍTICO DA "DÉCADA NEOLIBERAL"(1990-2000)
}

\author{
Giovanni Alves \\ Universidade Estadual Paulista
}

\begin{abstract}
RESUMO
O artigo apresenta um panorama dos principais contornos do mundo do trabalho no Brasil nos anos 1990. Denominamos esse periodo de "década neoliberal". Salientamos o desenvolvimento de um novo complexo de reestruturação produtiva e seu momento predominante (o toyotismo), o surgimento de um novo (e precário) mundo do trabalho e o advento da crise do sindicalismo, considerada expressão contingente da fragmentação da classe trabalhadora. Concluimos que hoje, mais do que nunca, o maior desafio do sindicalismo no Brasil na virada para o século XXI é romper com o viés burocrático-corporativo, organizar e mobilizar um contingente massivo de jovens operários e operárias, empregados e empregadas e, inclusive, trabalhadores por conta própria precarizados ou explorados pelo capital. Utilizarmos, numa perspectiva crítica, dados empíricos de livros e ensaios de pesquisadores da área de economia e da sociologia industrial e do trabalho no Brasil apresentados no decorrer da década passada.
\end{abstract}

PALAVRAS-CHAVE: trabalho; sindicalismo; neoliberalismo; toyotismo; desemprego.

\section{INTRODUÇÃO}

Durante a "década neoliberal" o Brasil apresentou taxas medíocres de crescimento do PIB (Produto Interno Bruto). Se nos anos 80, considerados a "década perdida", tivemos uma taxa média anual de crescimento do PIB de $3 \%$, nos anos 90 o crescimento anual médio do país atingiu apenas 1,7\% (até 1999) (POCHMANN, 2001, p. 9). A "década neoliberal" aparece, portanto, como uma "década mais que perdida". É a década da inserção subalterna do Brasil na mundialização do capital por meio de políticas neoliberais que acentuaram a lógica destrutiva do capital no país.

Apesar do controle da inflação via Plano Real, em 1994, o Brasil continuou apresentando a pior distribuição de renda do mundo industrializado. $\mathrm{O}$ "choque de capitalismo" da década passada tendeu a concentrar mais ainda a riqueza social e a tornar mais precário o mundo do trabalho. Por exemplo, segundo dados do Instituto Brasileiro de Geografia e Estatística (IBGE), na década de 1990 cresceu a distância salarial entre os $10 \%$ mais ricos e os 40\% mais pobres. Em 1992 a diferença entre o pico e a base da pirâmide nacional de rendimentos era de cerca de treze salários mínimos. Em 1999, chegou a aproximadamente dezessete (RENDA
CRESCE, 2001).

O reflexo da reprodução ampliada da desigualdade de renda sobre a estrutura de consumo no Brasil de primórdios da década de 2000 pode ser constatado pelos resultados da pesquisa da Associação Nacional de Empresas de Pesquisa (ANEP) e da Associação Brasileira dos Institutos de Pesquisas de Mercado (ABIPEM), com base em dados do IBGE, apresentado em 2002: cerca de $81 \%$ da população, ou quatro entre cinco pessoas, vivem na berlinda do que se produz e se consome. Os 137 milhões de brasileiros pertencentes às classes $\mathrm{C}, \mathrm{D}$ e $\mathrm{E}$, diz a pesquisa, possuem rendas mensais brutas inferiores a $\mathrm{R} \$ 1$ 125,00, restando-lhes, portanto, quase nenhum poder de escolha nas decisões de consumo (UMA NAÇÃO SEM CONSUMIDORES, 2002).

Apesar das descontinuidades e incertezas conjunturais no ciclo da economia brasileira, tornou-se perceptível no decorrer da "década neoliberal", tanto em períodos de recessão quanto em períodos de retomada do crescimento, o continuum de degradação do mundo do trabalho no país. A sensação de perda contínua no emprego, salário e condições de trabalho imprimiu a sua marca em contingentes maciços da PEA (População Economicamente Ativa), mesmo nos 
breves momentos de recuperação da economia brasileira.

A degradação estrutural do mundo do trabalho contribuiu sobremaneira para aprofundar o cenário de barbárie social. Os altos (e crescentes) índices de criminalidade nos centros metropolitanos atestam não apenas a falência do Estado brasileiro, objeto de devassa das políticas neoliberais, como o resultado cumulativo de um modo de produção social que se tornou não apenas incapaz de absorver contingentes maciços da força de trabalho, como demonstrou ser voraz em degradar emprego, salário e condições de trabalho de contingentes importantes do mundo do trabalho organizado (POCHMANN, 2001, p. 9).

O objetivo deste ensaio é tão-somente apresentar os principais aspectos das transformações da objetividade e subjetividade do mundo do trabalho na década de 1990 no Brasil. Após uma breve discussão sobre as conjunturas da "década neoliberal", elaboramos um panorama dos principais contornos do mundo do trabalho, na década de 1990, do capitalismo brasileiro. Salientaremos, por exemplo, o desenvolvimento do toyotismo sistêmico a partir da constituição de um novo complexo de reestruturação produtiva na indústria e serviços. Trataremos do surgimento de um novo (e precário) mundo do trabalho no Brasil, apresentando, a partir daí, um perfil da classe trabalhadora no país. Finalmente, ao tratarmos da fragmentação de classe, lidaremos com o desenvolvimento da crise do sindicalismo no Brasil. Além de utilizarmos, numa perspectiva crítica, dados empíricos de livros e ensaios de pesquisadores da área de economia e da sociologia industrial e do trabalho, procuramos utilizar, com o devido cuidado, e como ilustração estatística, alguns dados apresentados por institutos credenciados de pesquisa sócio-econômica, tais como IBGE, IPEA (Instituto de Pesquisas Econômicas Aplicadas) e DIEESE (Departamento Intersindical de Estudos Estatísticos e SócioEconômicos), e divulgados pela mídia mais qualificada (CartaCapital, Gazeta Mercantil, Folha de S. Paulo e O Estado de S. Paulo).

\section{CENÁRIOS DA GLOBALIZAÇÃO NO BRASIL}

A década de 1980 no Brasil caracterizou-se por altas taxas de inflação e baixo crescimento da economia. Se nos anos 1970 a economia brasileira teve um crescimento médio de $8,8 \%$ do PIB, nos anos 1980 essa taxa caiu para 3,0\% (POCHMANN, 2001). Desde a crise da dívida externa em 1981, o país permaneceu à margem do circuito financeiro internacional. A crise do regime militar e a abertura política num cenário hiperinflacionário contribuíram, de certo modo, para que o sindicalismo brasileiro demonstrasse, em comparação com o sindicalismo de outros países industrializados, uma singular combatividade e capacidade de mobilização social (ANTUNES, 1991, p. 87). É que, apesar da deterioração macroeconômica, o Brasil ainda era uma economia protegida da concorrência internacional, com um mundo do trabalho estruturado em algumas categorias assalariadas organizadas num aparato sindical-corporativo unitário que garantia um poder de barganha relativo e um setor público cuja dinâmica positiva do emprego garantia a pequena deterioração do mercado de trabalho (ALMEIDA, 1996)

Apesar de a informalização do mercado de trabalho constituir um aspecto estrutural de um país capitalista dependente e subalterno e de desenvolvimento industrial retardatário, ela não assumia ainda proporções significativas, como veio a ocorrer na década seguinte (MALAGUTI, 2001). Desse modo, o trabalho no Brasil durante a década de 1980 era relativamente integrado, possuindo um núcleo orgânico de assalariados ligados à economia formal, de grandes empresas públicas e corporações privadas nacionais e estrangeiras, que representavam, em si, a promessa da modernidade fordista: um fordismo periférico, utilizando a expressão de Lipietz, com garantias de direitos sociais e benefícios trabalhistas, com carreiras internas e modernos estatutos de regulação salarial para contingentes de assalariados do setor privado e do setor público (LIPIETZ, 1988, p. 176).

A nova crise de acumulação do capitalismo brasileiro, que se originou em meados da década de 1970 e desenvolveu-se na década seguinte, colocou para a grande burguesia a necessidade de uma reestruturação radical da economia e do Estado e do seu modo de inserção no sistema mundial do capital. Na última metade dos anos 1980, sob o governo Sarney, tivemos os fracassos dos planos de estabilização monetária (planos Cruzado I e II e Verão) e a tentativa, sem muito sucesso, de a Constituição de 1988 incorporar pretensões reformistas de uma burguesia liberal num contexto político interno de ascensão dos movimentos sociais e da oposição política de esquerda. Foi preciso a derrota política da Frente Brasil Popular (Partido dos Trabalhadores, Partido Comunista do Brasil e Partido Socialista Brasileiro) 
e seu candidato Luis Inácio Lula da Silva, nas eleições para Presidente da República, em dezembro de 1989, para que a grande burguesia pudessem abrir o delicado caminho político e social das reformas estruturais da economia e do Estado capitalista (a Frente Brasil Popular e seu candidato representavam o espírito de resistência política e sindical de massas, que vicejou nos anos 1980).

A vitória eleitoral das elites liberalconservadoras, com Fernando Collor de Mello, do PRN (Partido da Reconstrução Nacional), em 1989, criou as condições políticas necessárias para uma série de reformas do capitalismo brasileiro voltadas, principalmente, a facilitar o acesso do país à pletora de capitais financeiros internacionais, sedentos de valorização fíctícia. O livre acesso à mundialização do capital, segundo os arautos neoliberais, poderia contribuir para a constituição de um novo padrão de financiamento e de investimento do capitalismo brasileiro, capaz de dar um novo impulso à acumulação de capital no Brasil (GOLDESTEIN, 1994, p. 99).

\section{II.1. As conjunturas dos anos 1990}

A década de 1990 caracterizou-se por uma elevada oscilação no nível de atividade e taxas de expansão da economia próximas do ritmo de variação da população. Apesar de o Brasil ter conseguido ser um celeiro de bons negócios capitalistas no período de 1994-1997, como atestam os balanços das empresas, uma análise dos indicadores do mercado de trabalho demonstrou, por outro lado, uma perda cumulativa de postos de trabalho na indústria, como demonstra o crescimento persistente do desemprego aberto e da precarização de estatutos salariais, principalmente nos "núcleos modernos" do mundo do trabalho (POCHMANN, 1999, p. 65).

É possível discriminar alguns períodos da economia brasileira nesse período que contribuíram para o desenvolvimento de tendências do mundo do trabalho e do sindicalismo. As conjunturas internas da economia e da política vinculava-se, de certo modo, à dinâmica da economia global, que no decorrer da década apresentou, principalmente até 1997 , um período de vigorosa expansão do capital financeiro, apreendido como "globalização" (ou "mundialização"). Foi nessa década que o capitalismo brasileiro buscou inserir-se na mundialização do capital, por meio de um novo modelo de crescimento e acumulação, cuja vulnerabilidade sistêmica se tornaria perceptível em meados da década, a partir da crise do México em 1995. Após 1997, com a crise asiática, da Rússia, da Coréia do Sul e, a seguir, em 2000, com o estouro lento e gradual da "bolha especulativa" de Wall Street e do índice Nasdaq, assim como a crise terminal do modelo neoliberal na Argentina, o sistema mundial do capital entraria em um período de instabilidade sistêmica e de crises financeiras.

Apresentaremos a seguir algumas características das sucessivas conjunturas da "década neoliberal": 1990-1993, período do neoliberalismo selvagem; 1994-1997, período do neoliberalismo claudicante, 1998-2000, a crise da globalização. É a partir dessa "totalidade concreta" da economia capitalista no Brasil que podemos situar o desenvolvimento do trabalho e do sindicalismo na "década neoliberal".

GRÁFICO 1 - Taxa anual média do PIB (Brasil)

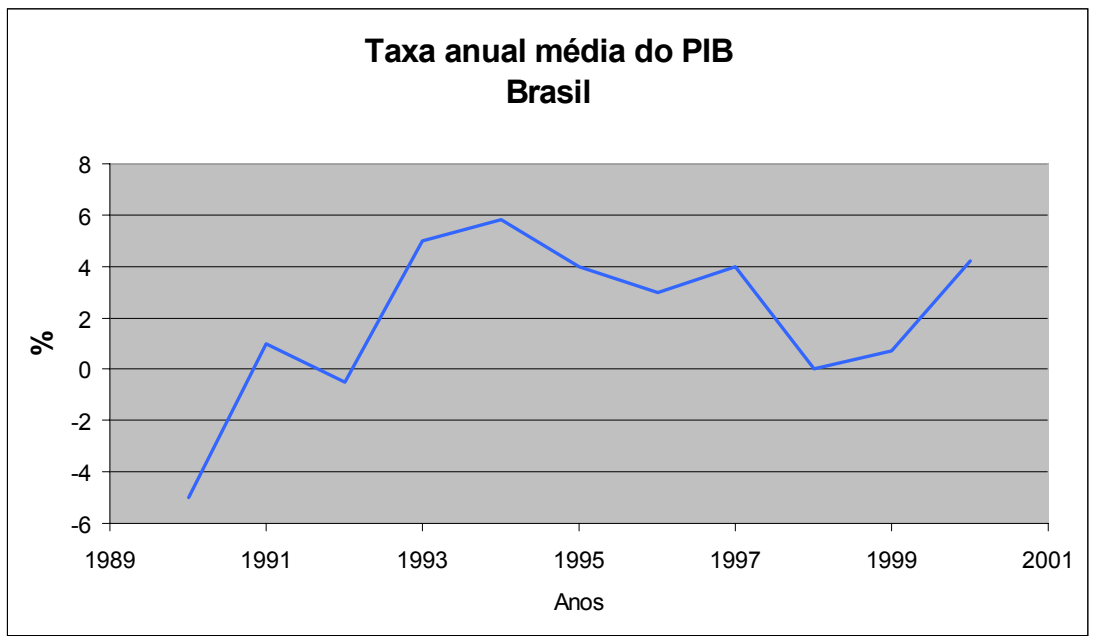

Fonte: IBGE (2001a, p. 38). 


\section{a) 1990-1993: neoliberalismo selvagem}

A "década neoliberal" teve início com uma profunda recessão decorrente do Plano Collor I. Em fevereiro de 1990, a economia brasileira foi atingida pelos fracassados Planos de estabilização do Brasil Novo, os planos Collor I e II, que conduziram o país a uma profunda recessão (1990-1992), com o PIB acusando uma queda acumulada de quase $10 \%$ entre 1990 e 1992. Comprometido com a política neoliberal, Collor de Mello deu início à abertura comercial, via eliminação de barreiras não-tarifárias às compras externas e progressiva redução das alíquotas de importação. Cabe salientar que essa estratégia teve início quase no apagar das luzes do governo Sarney em 1988, sendo mantido pelo governo Collor e aprofundado em 1994, antecipando os acordos fixados no âmbito do Mercosul, rumo à adoção da Tarifa Externa Comum e aderindo aos requisitos definidos pelos movimentos próliberalização comercial da OMC (Organização Mundial do Comércio).

Além disso, o governo Collor deu início a um programa de reforma do Estado, cujo "núcleo duro" consistiu no programa de privatização, sob a gestão do BNDES - o Programa Nacional de Desestatização. A incapacidade hegemônica de Fernando Collor em estabilizar a economia e conduzir as reformas liberais significou a perda de seu apoio em importantes frações da burguesia brasileira. Diante de denúncias de corrupção, Collor teve seu impedimento em outubro de 1992. O espaço político dominante foi ocupado por uma nova composição neoliberal, articulada em torno do governo Itamar Franco, que criou, a seguir, as condições macroeconômicas para o lançamento do Plano Real, que demonstrou ser vitorioso em reduzir drasticamente a inflação no país. Nas eleições de 1994, foi eleito para Presidente da República o candidato governista da aliança PSDBPFL, Fernando Henrique Cardoso. Desde 1993, a economia brasileira demonstrava sinais de recuperação, após a profunda recessão do período Collor: de certo modo, o Plano Real sustentou-se em uma arquitetura macroeconômica que aproveitava as facilidades da conjuntura financeira internacional (FILGUEIRAS, 2000, p. 64).

\section{b) 1994-1997: o neoliberalismo claudicante}

Com o governo Cardoso constituiu-se, a partir de uma coalizão política liberal-conservadora bastante ampla, uma nova hegemonia burguesa, capaz de articular as elites políticas, regionais e nacionais, num programa econômico voltado para a estabilização monetária e a reforma do Estado capitalista no país. Criaram-se novas perspectivas para investimentos privados, internos e externos; no plano geopolítico regional, o Mercosul teve um impulso político considerável.

Um dos traços característicos da conjuntura da economia brasileira sob o governo Cardoso foi sua instabilidade estrutural, decorrente da política econômica do stop and go, determinada pelas flutuações sistêmicas da economia mundial. A partir de 1994, impulsionado pelo Plano Real, ocorreu uma pequena retomada do crescimento da economia brasileira. Em virtude da redução drástica dos índices inflacionários (de 46,60\% em junho de 1994, para 3,34\% em agosto do mesmo ano), ocorreu um crescimento das atividades de consumo, produção e emprego (que iria até março de 1995). Em virtude da crise do México de dezembro de 1994 e da fuga de capitais, ocorreu, em abril de 1995, a primeira inflexão da trajetória de crescimento pós-Real. O governo Cardoso precisou desacelerar a economia para evitar uma crise de balanço de pagamentos, que o estava levando ao mesmo impasse do México. O retorno à normalidade nos mercados financeiros internacionais, a partir de abril de 1996, bem como o melhor desempenho das contas externas do país, promoveu uma nova retomada de crescimento da economia, que iria até junho de 1997. Ocorreu uma outra inflexão no ritmo das atividades em julho de 1997, em virtude da crise dos países asiáticos e da crise da Rússia; esse período recessivo da economia prosseguiu até dezembro de 1998. Finalmente, em janeiro de 1999 ocorreu a desvalorização do Real (idem, p. 135).

A política neoliberal do governo Cardoso contribuiu para criar as condições macroeconômicas propícias, mas bastante vulneráveis, de um novo (e instável) ciclo de acumulação no Brasil. Ela aproveitou-se da liquidez do mercado financeiro internacional. Nesse período, em 1994, a partir do governo Clinton, a economia americana recuperou-se de uma recessão e teve início um dos mais significativos períodos de expansão da economia americana no século XX (BATISTA JR., 2000, p. 121).

Apesar da crise do México, em 1995, o cenário internacional caracterizou-se por uma economia mundial exuberante em seu ciclo de valorização fictícia. Um ciclo de crescimento do capital financeiro, cujo epicentro foi o EUA sob o governo Clinton, disseminou-se pelo Sudeste Asiático, 
México e Rússia. A ideologia da globalização, mesmo prejudicada pela crise mexicana, foi adotado pelos governos neoliberais para legitimar suas políticas de mercado (CHESNAIS, 1996, p. 29).

Mesmo com o alerta sobre os riscos de uma "exuberância irracional" (utilizando a expressão cunhada pelo Presidente do Federal Reserve, banco central americano, Alan Greenspan, em 1996), a ideologia de uma "nova economia" levou empreendedores capitalistas a realizarem grandes negócios, principalmente nas áreas de telecomunicações e ìnternet. No centro capitalista mais desenvolvido (a "Tríade", isto é, EUA, União Européia e Japão), ocorreram fusões e aquisições bilionárias, demonstrando que o capitalismo financeiro crescia, centralizando e concentrando mais capital em setores estratégicos de acumulação (ALVES, 2001, p . 52).

Por exemplo, desde 1994, no Brasil, as fusões e aquisições na indústria e no setor de serviços cresceram cerca de $22 \%$ ao ano (com cerca de 175 operações), atingindo seu pico em 1997 (com cerca de 370 operações), e com a presença significativa do capital estrangeiro. O boom de aquisições e fusões não significou necessariamente acréscimo na capacidade produtiva do país; na verdade, o capital financeiro aproveitava-se de oportunidades preciosas para seu crescimento exuberante nas "economias emergentes".

Nesse período, o fluxo de Investimentos Diretos Externos (IDE) cresceu bastante, não apenas entre os próprios países capitalistas da "Tríade", para onde se dirigiria o maior volume de IDE, mas em direção a alguns países capitalistas industrializados não-desenvolvidos (a China e o Brasil merecendo destaque). O Programa Nacional de Desestatização, desenvolvido no decorrer da "década neoliberal", desde o governo Collor, principalmente com a privatização das empresas siderúrgicas, de telecomunicações e de energia elétrica (ainda incompleto), tendeu a atrair uma pletora de capitais externos. Enquanto os governos Collor e Itamar priorizaram a transferência de ativos públicos dos segmentos de insumos básicos (siderurgia, fertilizantes e petroquímica), o governo Cardoso privilegiaria as áreas de transporte, mineração e telecomunicações (BIONDI, 1999; 2000).

A política de abertura comercial e o câmbio sobrevalorizado contribuíram para um ciclo de falências, fusões e aquisições nas empresas brasileiras. Aprofundou-se a desnacionalização da economia brasileira (GONÇALVES, 1999). O capital estrangeiro, que correspondia a $36 \%$ do faturamento dos 350 maiores grupos do país em 1991, passou para 53,5\% no final de 1999 . A participação estrangeira no faturamento das maiores empresas do país subiu 146\% entre 1991 e 1999 (MÚLTIS CRESCEM 146\%, 2002).

Por outro lado, as elevadas taxas de juros acenavam com generosas taxas de rentabilidade para o especulador estrangeiro, sedento de valorização fictícia. No decorrer da "década neoliberal", as taxas de juros mantiveram-se num patamar elevadíssimo, prejudicando qualquer crescimento sustentável do investimento produtivo no país. A manutenção das taxas de juros elevadas tornou-se uma das principais variáveis nas políticas de estabilização neoliberal (FILGUEIRAS, 2000, p. 98).

É nesse cenário de inserção subalterna na mundialização do capital que se acelerou o processo de reestruturação produtiva, aprofundando-se as tendências de transformação da estrutura de produção capitalista. $\mathrm{O}$ "choque de competitividade", que percorreu os governos Collor, Itamar Franco e Fernando Henrique Cardoso, tornou-se um traço marcante da "década neoliberal”. Desde o governo Collor constituíramse diretrizes voltadas a dar maiores níveis de eficiência operacional, produtividade e competitividade próximas dos paradigmas internacionais.

Os dois instrumentos oficiais foram o Programa de Competitividade Industrial (PCI) e o Programa Brasileiro de Qualidade e Produtividade (PBQP), variantes do documento Diretrizes gerais para a política industrial e de comércio exterior (PICE), editado em 1990. O braço financeiro daqueles programas era representado pelo BNDES, ancorado na estratégia de "integração competitiva" (definida naquela instituição ainda nos anos 1980).

Na verdade, priorizou-se a alocação privilegiada de recursos financeiros para o desenvolvimento do que podemos denominar de "toyotismo sistêmico", ou seja, a racionalização organizacional de toda a empresa segundo os dispositivos toyotistas, com programas de qualidade total, ênfase no envolvimento estimulado da força de trabalho, racionalização das linhas de produção, substituição de processos, além de sistemas de automação e iniciativas voltadas ao aprimoramento tecnológico (ALVES, 2000, p. 99) ${ }^{1}$. 
Após 1994, o mercado de trabalho no Brasil tendeu a aprofundar seu ajuste estrutural, crescendo, a partir daí, o índice de desemprego aberto, em virtude não apenas das políticas neoliberais, que propiciaram o desmonte de cadeias produtivas da indústria nacional num cenário de crescimento medíocre da economia brasileira, mas do novo complexo de reestruturação produtiva, impulsionado pelo "choque de competitividade".

\section{c) 1997-2000: a nova crise da globalização}

A partir de julho de 1997 e até 2000, ocorreu uma alteração qualitativa na conjuntura da economia brasileira, devido à "nova crise da globalização", que atingiu o Sudeste Asiático, Coréia do Sul, Rússia e Argentina (cujo modelo neoliberal entra numa "crise terminal" dramática de amplas proporções). A crise estrutural da Argentina tendeu a colocar o projeto de integração do Cone Sul, o Mercosul, num compasso de espera.

Diante das perspectivas de "crise da globalização", com seu epicentro nos EUA, os estrategistas do Departamento de Estado americano colocam a necessidade do aprofundamento da integração continental. Na verdade, a ALCA (Área do Livre Comércio das Américas), tende a significar para o capital oligopólico uma expansão possível de mercado nas condições de uma crise de superprodução, que atinge o núcleo do capital hegemônico e que assume tamanha proporção que nem as rodadas de liberalização comercial, levadas a cabo pela OMC nos anos 1990, nem a perspectiva de abertura do exuberante mercado da China continental (por meio de seu ingresso na OMC), conseguiram ser suficientes para acalmar a sanha de valorização. Exige-se mais integração

1 Ao adotarmos a expressão "toyotismo sistêmico" procuramos ressaltar o caráter ampliado (e totalizante) da modernização das grandes empresas na década de 1990, em contraste com o "toyotismo restrito" da década anterior. Elas passaram não apenas a incorporar novas tecnologias microeletrônicas na produção, mas a adotar princípios de organização do trabalho de cariz toyotista. É claro que o toyotismo não é o único modelo industrial ou de organização vigente da produção capitalista no Brasil, mas ele tendeu a tornar-se o "momento predominante" do processo de reestruturação produtiva que se instala nas grandes empresas. Ele articula-se, de modo complexo (e persistente), com dispositivos tayloristo-fordistas. Desse modo, consideramos que o toyotismo não pode ser considerado uma mera ruptura com os modos de racionalização do trabalho pretéritos, mas representa um desenvolvimento qualitativamente novo da racionalização capitalista (que conserva e supera a lógica regional e abertura de mercados ainda cativos, sem uma reciprocidade para produtos brasileiros.

A perspectiva é de acirramento de contradições não-antagônicas (ou intracapitalistas) entre as frações hegemônicas do capital financeiro com pretensões globais, e frações do capital de inserção local ou regional. Além disso, a ALCA tenderia a proporcionar não apenas mercado interno, mas economias de escala para as corporações transnacionais, cada vez mais concentradas e competitivas no mercado mundial. Ela representa um momento mais desenvolvido da lógica intrínseca da mundialização do capital.

Em decorrência da desvalorização cambial de 1999, no bojo da crise da globalização no Brasil, tivemos, em 2000, uma pequena retomada do crescimento da economia brasileira, puxada pela redução da taxa de juros, substituição de importações e o crescimento das exportações. Como atestam os indicadores do IBGE, o pequeno crescimento da economia conseguiu promover uma melhoria relativa do emprego nas regiões industrializadas.

Entretanto, apesar da taxa de desemprego ter apresentado um leve recuo (devido ao crescimento da ocupação), a renda média dos trabalhadores teve queda de $2,1 \%$. Na região metropolitana de São Paulo, onde se concentra um dos maiores contingentes de assalariados do país, registrou-se a maior queda dos rendimentos do trabalho. Os cada vez mais curtos e instáveis ciclos de crescimento da economia capitalista no Brasil não conseguem ocultar mais a lógica predatória do capital. Desde 1997, quando atingiu seu pico no governo Cardoso, a renda média dos trabalhadores da região metropolitana de São Paulo tem caído, de R\$ 138,78 em 1997 (tomando julho de 1994 como base 100) para $R \$ 115,34$ em 2000 (EMPREGOS APARECEM, 2000).

tayloristo-fordista). Com o toyotismo, o envolvimento da força de trabalho pelo capital tende a assumir formas mais completas e desenvolvidas. Além disso, cabe salientar que o toyotismo tende a expressar a nova racionalidade intrafábrica, que se contrasta, de modo funcional, com a irracionalidade societal (desemprego e precarização do mundo do trabalho). De fato, não conseguiu articular-se como um modo de desenvolvimento capitalista, tal como o fordismo, na acepção da escola regulacionista. Para uma análise mais desenvolvida da dialética continuidade-descontinuidade do taylorismofordismo-toyotismo e da lógica do toyotismo, ver Alves (1999). 
Numa pesquisa ampla, divulgada em 2002, intitulada $A$ situação do trabalho no Brasil, o DIEESE destacou que na década de 1990 o salário médio real do trabalhador caiu $18,8 \%$ na região metropolitana de São Paulo (o encolhimento do salário médio do trabalhador, segundo o DIEESE, seria decorrente do crescente desemprego no período). Mas a queda da renda média tenderia a expressar, de certo modo, não apenas o aumento do desemprego nos anos 1990, mas a informalização crescente do mundo do trabalho. Por exemplo, em meados de 2000, o IBGE salientou que, dos 822 mil empregos criados nas seis regiões metropolitanas, apenas 62 mil foram com carteira, ou seja, 7,5\% do total (MENOS EMPREGO, 2000).

GRÁFICO 2 - Salário médio mensal dos empregados de atividade (Região Metropolitana de São Paulo 1989-1999)

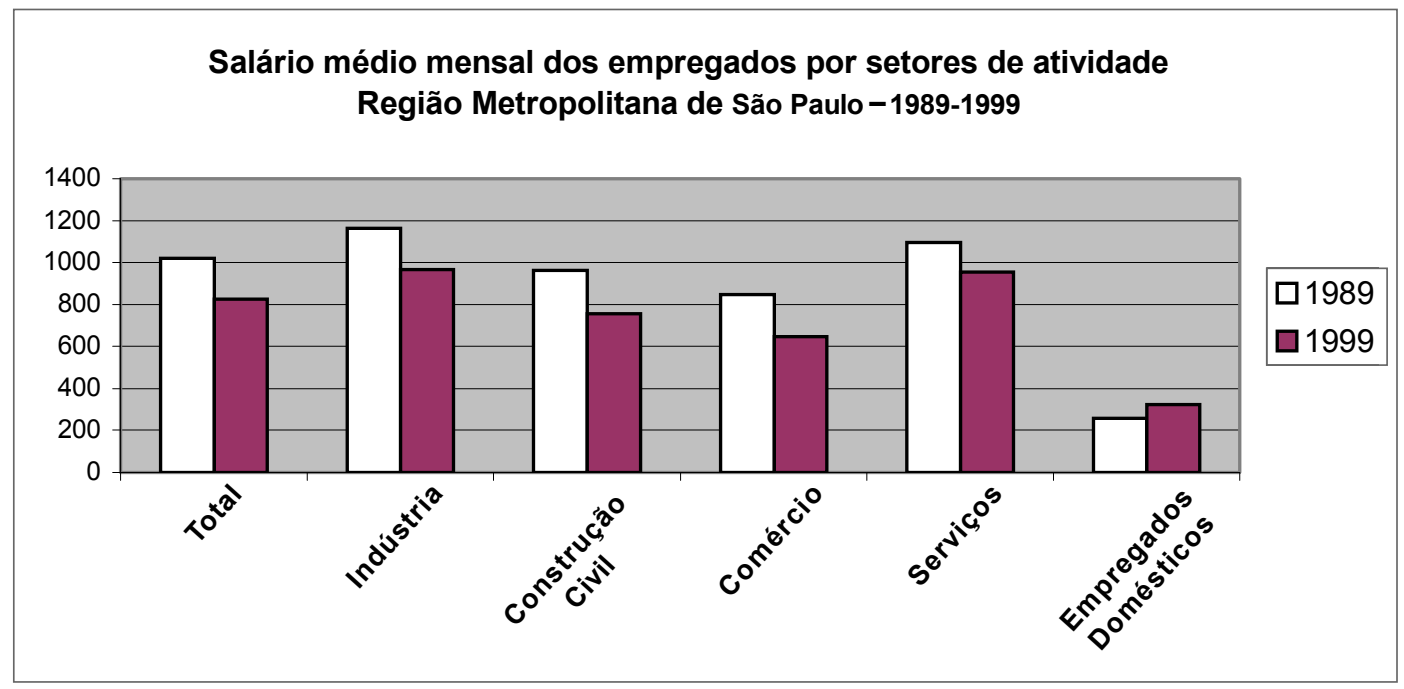

Fonte: DIEESE (2002, p. 32).

\section{A DEGRADAÇÃO DA OBJETIVIDADE (E SUBJETIVIDADE) DO TRABALHO NO BRASIL}

Se por um lado é perceptível a descontinuidade de conjuntura na economia capitalista no Brasil nos anos 1990, principalmente no tocante a oscilações no PIB, o que merece ser destacado, por outro lado, é a linha contínua de degradação do mundo do trabalho. Apesar das novas vulnerabilidades sistêmicas, as políticas neoliberais contribuíram para a constituição de um cenário propicio para os negócios capitalistas no país.

$\mathrm{Na}$ ótica do capital, a "década neoliberal" constituiu um sistema progressivo de novas sinergias para a valorização capitalista, principalmente em sua forma fictícia (como atesta a alta rentabilidade dos bancos nos anos 1990). Entre-tanto, as políticas neoliberais e o novo complexo de reestruturação produtiva conseguiram alterar a dinâmica da sociabilidade do trabalho no Brasil, degradando-a, tanto no sentido objetivo, ou seja, no tocante à materialidade da organização do processo de trabalho, quanto no sentido subjetivo, principalmente no plano da consciência de classe.

A linha contínua de degradação do mundo do trabalho que delineamos na "década neoliberal" significa um processo estrutural de transformações da objetividade e da subjetividade da classe trabalhadora no Brasil, em especial do setor industrial, com impactos decisivos no sindicalismo e nos movimentos sociais urbanos e rurais. É provável que os anos 1990 tenham sido um importante "elo de transição" para uma nova configuração do mundo do trabalho, de acordo com a nova dinâmica da acumulação capitalista mundial.

É provável que a noção de precariedade perca seu caráter atípico e torne-se um nexo institucional, e, portanto, típico, da própria implicação assalariada nas condições do novo regime de acumulação flexível. Na verdade, a idéia de precariedade conduz-se a um tempo passado que tende a tornar-se distante e perder sua presença crítica, diante da nova etapa capitalista. 
GRÁFICO 3 - Índice-síntese do mercado de trabalho (Região Metropolitana de São Paulo) ${ }^{2}$

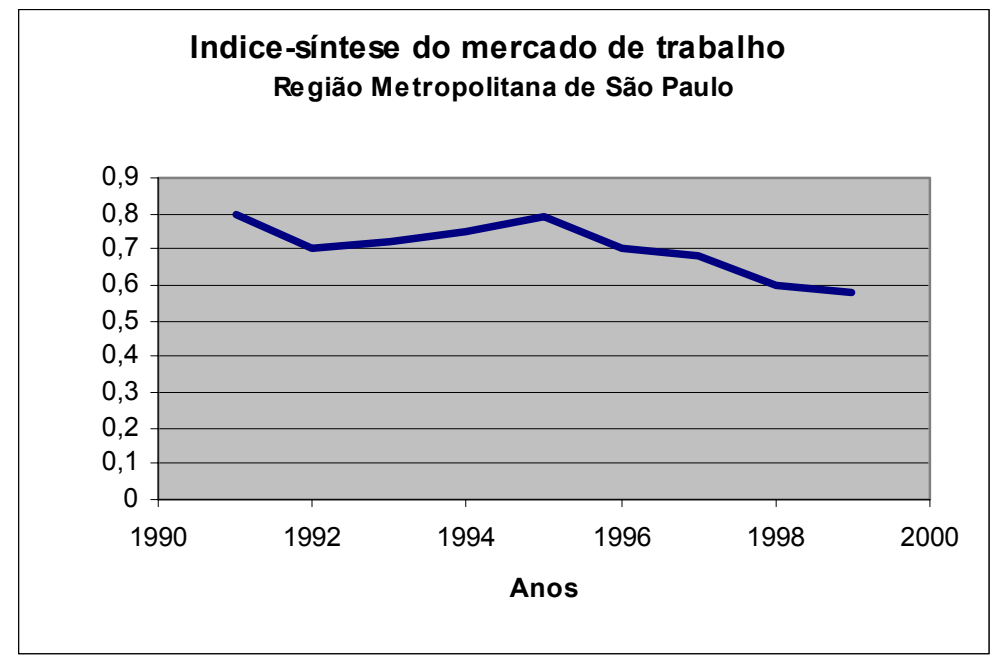

Fonte: PME-IBGE (IBGE, 2001b, p. 61).

Podemos caracterizar como principais traços da transformação da objetividade (e subjetividade) do mundo do trabalho no Brasil no decorrer da "década neoliberal": 1) o desenvolvimento sistêmico de um novo complexo de reestruturação produtiva; 2) a emergência de um novo (e precário) mundo do trabalho, e 3 ) a fragmentação de classe no Brasil (a crise do sindicalismo brasileiro). É o que apresentaremos a seguir.

\section{III.1. O desenvolvimento do novo complexo de reestruturação produtiva}

Ao analisarmos a "década neoliberal" podemos constatar o impacto disruptivo do "choque capitalista" na objetividade do mundo do trabalho no Brasil, seja através das políticas neoliberais (principalmente a abertura comercial com câmbio sobrevalorizado até 1999, que desarticulou cadeias produtivas e promoveu o desemprego em várias regiões industriais), seja por meio do novo complexo de reestruturação produtiva (isto é, o desenvolvimento ampliado de uma nova ofensiva do capital na produção).

É claro que não podemos atribuir tão-somente às políticas neoliberais a determinação exclusiva das transformações do mundo do trabalho no Brasil nos anos 1990. Existem determinações essenciais que se vinculam às dinâmicas estruturais das transformações produtivas do capitalismo mundial. Desde a grande crise capitalista de meados dos

2 O índice varia de zero a 1. Quanto maior (mais próximo de 1): melhores as condições do mercado de trabalho. anos 1970, no "núcleo orgânico" do sistema mundial do capital, ocorria o desenvolvimento ampliado de um novo regime de acumulação flexível, vinculado à $3^{\mathrm{a}}$ Revolução Tecnológica e à mundialização do capital. Surgiu um novo complexo de reestruturação produtiva cujo "momento predominante" foi dado pelo toyotismo, a nova ideologia orgânica da produção (ALVES, 1999 , p. 93$)^{3}$, enquanto ocorriam mutações estruturais na base técnica (e organizacional) do sistema produtor de mercadorias que atingiram o mundo do trabalho industrial e de serviços nos países capitalistas centrais (SCHAFF, 1990).

No caso do Brasil, desde meados dos anos 1980 temos indícios do surgimento de uma nova base material de produção capitalista, principalmente nas corporações industriais mais integradas à lógica do mercado mundial. As novas estratégias de concorrência globais das grandes empresas transnacionais, muitas delas atuando no Brasil, impulsionaram inovações organizacionais

\footnotetext{
3 Utilizamos a expressão "complexo de reestruturação produtiva" não apenas como preciosismo estilístico, mas para salientar seu caráter totalizante (e totalizador), amplo e multifacético, que articula, no tocante à sua lógica de desenvolvimento interno, um "momento predominante" (o toyotismo) com "momentos não-predominantes" (taylorismo-fordismo), e que é composto por processos tecnológicos, organizacionais e institucionais voltadas para o incremento da exploração relativa (e absoluta) da força de trabalho. Ele atinge a grande empresa e tende a disseminarse pelas rede de subcontratação, assumindo formas diferenciadas e combinadas.
} 
baseadas na lógica toyotista (CASTRO, 1995, p. $15)$.

É claro que, nesse periodo, o toyotismo ainda assumia uma dimensão restrita. no que temos denominado de "toyotismo restrito" (ALVES, 2000, p. 120). Apenas na "década neoliberal" é que observamos um impulso significativo do toyotismo no Brasil, assumindo uma dimensão sistêmica, no que denominaremos de "toyotismo sistêmico". Pelos menos desde 1985, categorias assalariadas importantes, como a de metalúrgicos (do ABC paulista) e bancários (de importantes conglomerados financeiros, como Bradesco e Itaú), por exemplo, tornaram-se alvos de um complexo de reestruturação produtiva, cujo "momento predominante" é a lógica toyotista (ALVES, 1995, p. 109).

Foi a partir do "choque de competitividade" da "década neoliberal" que ocorreu o desenvolvimento sistêmico do complexo de reestruturação produtiva, que se caracterizou, por um lado, pela introdução de novas tecnologias microeletrônicas na produção, e por outro lado, pelo desenvolvimento de novas formas de organização da produção capitalista que caracterizamos como sendo o toyotismo sistêmico com seus nexos contingentes, tais como just-intime, kan-ban, kaizen, terceirização, trabalho em equipe, programas de qualidade total, sistemas de remuneração flexível etc. (ALVES, 2000, p. 101).

O toyotismo sistêmico tendeu a disseminar-se não apenas no core das corporações industriais e de serviços, mas na borda periférica do sistema industrial e de serviços, através das suas redes de subcontratação, constituídas por médias e pequenas empresas. A prática da terceirização, que teve um impulso notável na década passada, contribuiu para a constituição ampliada de redes de subcontratação (DRUCK, 1999). A maior preocupação com a qualidade final do produto e do serviço e a busca contínua de redução de custos, exigiu das empresas terceirizadas (que, inclusive passaram a terceirizar algumas atividades), não apenas o incremento de seu padrão tecnológico, mas uma reorganização do processo de trabalho e da gestão da força de trabalho (MARTINS \& RAMALHO, 1994).

Foi no bojo da lógica do toyotismo que surgiram novos modelos de organização industrial centrados na idéia de uma empresa flexível, fluida e difusa (BIHR, 1998). A empresa toyotista tende a ser uma empresa enxuta que se constitui em rede (firme réseau, impresa rete ou network firm). Em alguns setores importantes do novo mundo industrial e de serviços a corporação principal tendeu a se concentrar na criação e marketing e no controle do desenvolvimento da tecnologia (com a propriedade da marca passando a exercer a função de um capital fictício). A empresa terceirizada de grande porte, por outro lado, tendeu a concentrarse na produção e na logística manufatureira. (ANTONELLI, 1988).

A partir de meados dos anos 1990, o novo modelo de organização da produção de mercadorias tendeu a surgir e a desenvolver-se nos setores mais dinâmicos da economia brasileira. É o caso de algumas corporações da indústria de informática e telefonia. Por exemplo, segundo dados de 2000, a Nokia e a IBM suspenderam a fabricação de seus produtos no Brasil e transferiram a atividade para empresas especializadas em manufatura para terceiros (TECNOLOGIA PRODUZ INDÚSTRIA, 2000).

Mas é a indústria automobilística que tem sido um celeiros de inovações na organização da produção capitalista no Brasil. Desde meados da década passada, ela implantou no país seus novos modelos produtivos e suas mais modernas e inovadoras fábricas, como o da Volkswagem em Resende (RJ), que introduziu o conceito de "consórcio modular", o da Ford em Camaçari (BA) e da General Motors em Gravataí (RS) (o mais moderno complexo industrial da GM no mundo) (ARBIX \& ZILBOVICIUS, 1997). Em 2001, a Volkswagen do Brasil anunciou, por exemplo, a terceirização do setor de logística operacional da suas fábricas de São Bernardo do Campo (SP) e Taubaté (SP): "A Schnellecke [uma das maiores empresas mundiais em logística automotiva, contratada pela Volkswagem do Brasil] fará trabalho conjunto com a Volks para aprimorar os sistemas de entrega de autopeças nos sistemas just-in-time e kanban" (VOLKSWAGEM TERCEIRIZA, 2001).

O desenvolvimento do novo complexo de reestruturação produtiva contribuiu, de certo modo, para o aumento da produtividade da força de trabalho no Brasil (decorrente não apenas de investimentos em capital fixo, mas do incremento da taxa de mais-valia absoluta da força de trabalho - por exemplo, o aumento das horas-extra).

De acordo com dados do IPEA, de 1991 a 1998 a taxa geral de produtividade do país foi de 2,53\% ao ano, concentrando-se principalmente nos 
setores industriais - os que mais têm deslocado força de trabalho para o setor de serviços. No caso da indústria automobilística, que destacamos acima, a sua produtividade cresceu a uma taxa média de 9,4\% ao ano (BONELLI \& FONSECA, 1998, p. 52).

O aumento da competitividade no setor automobilístico no Brasil significou a adoção pelas montadoras de técnicas de produção cada vez mais modernas e enxutas (cabe salientar que em 2001, o Brasil passou a abrigar 17 marcas, um recorde mundial) (FÁBRICAS BRASILEIRAS, 2001). Por isso, tornou-se claro, na década passada, que o aumento da produção não significaria aumento dos postos de trabalho. Segundo dados de 2000, enquanto a produção na indústria aumentou $6,5 \%$, com o Brasil tendo um crescimento do PIB de $4,4 \%$, o nível de ocupação cresceu apenas $0,6 \%$.

GRÁFICO 4 - Emprego na indústria, de acordo com o PME (1990: base 100)

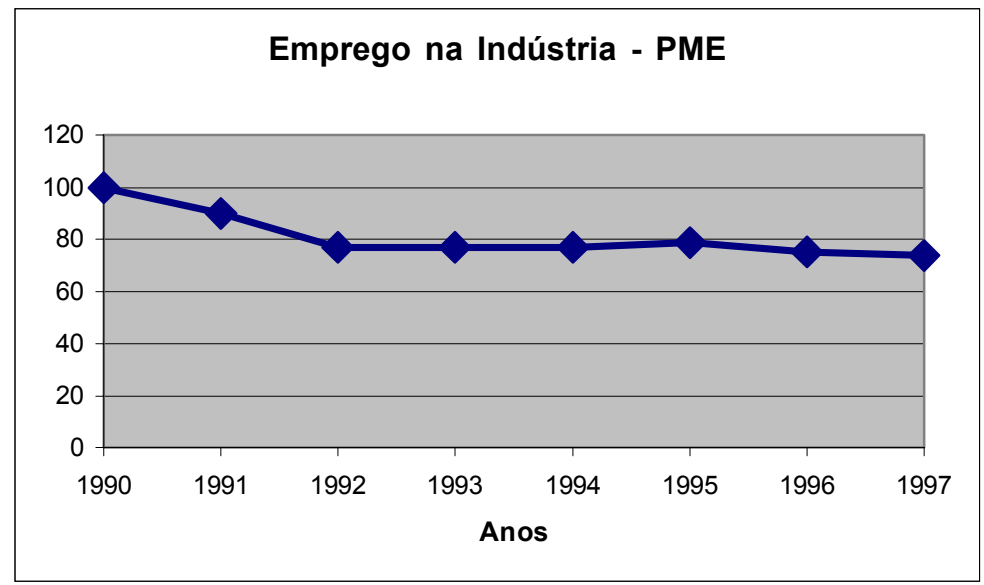

Fonte: IBGE (2001b, p. 43).

É claro que, além de determinações estruturais ligadas à lógica sistêmica do capitalismo mundial, tais como o desenvolvimento do novo complexo de reestruturação produtiva, determinações políticas contribuíram para a implosão da objetividade e da subjetividade de classe do trabalho industrial. Por exemplo, os eixos centrais das políticas neoliberais, como a abertura comercial e a sobrevalorização cambial (até 1998), contribuíram para a rarefação da cadeia produtiva na indústria brasileira. A importação de insumos passou a ter maior peso dentro da cadeia produtiva nacional em decorrência da abertura da economia. Desse modo, tendeu a ocorrer um descolamento entre produção e nível de ocupação (INDÚSTRIA BRASILEIRA PRODUZ, 2000).

Outro exemplo típico do novo complexo de reestruturação produtiva ocorreu no setor bancário, onde a introdução de novas tecnologias microeletrônicas voltadas para o auto-atendimento (e o serviço on-line) e a disseminação da prática da terceirização (e de novas formas de gestão do trabalho) contribuiu para "enxugar" a força de trabalho bancária no Brasil. O "enxugamento" da categoria de trabalhadores bancários no Brasil nos anos 1990 atingiu cerca de $40 \%$ do estoque de empregos no setor. Por exemplo, entre 1994 e 1996 cerca de 140000 bancários perderam o emprego. Se em 1989 a categoria bancária era constituída por cerca de 811000 trabalhadores, em 2001 esse número caíra para 394000 trabalhadores (o número médio de bancário por agência, em 1994, era de 30,2; em 2000, caiu para 24,2, atingindo, em cheio, a função de escriturários) (ARAÚJO, CARTONI \& JUSTO, 1999).

Entretanto, cabe salientar que o "enxugamento" da categoria bancária atingiu principalmente as atividades-meio, com o crescimento alucinante do ritmo de terceirização (nas funções de analistas, programadores e técnicos). O "enxugamento" da categoria bancária oculta sua fragmentação, com um contingente maciço de bancários exercendo as mesmas atividades de serviço bancário via empresas prestadoras de serviço (não sendo, portanto, reconhecidos como empregados bancários).

a) Toyotismo e a captura da subjetividade da força de trabalho

Temos salientado que o novo complexo de reestruturação produtiva possui como seu "mo- 
mento predominante" a lógica do toyotismo. É uma nova forma de organização da produção capitalista que busca constituir uma captura da subjetividade da força de trabalho, um novo tipo de envolvimento estimulado, adequada à nova base técnica da produção de mercadorias (ALVES, 1999, p. 109).

Para a adoção da nova ideologia orgânica da produção capitalista, tornou-se necessária uma "reestruturação" da subjetividade da classe. Por isso, o processo de reestruturação produtiva não pode ser visto apenas em sua dimensão objetivomaterial, mas principalmente em seus nexos subjetivo-ideológicos. Ele tende a significar, em última instância, uma metamorfose da subjetividade da força de trabalho, seja em seus aspectos geracionais, seja em seus aspectos político-ideológicos.

Os processos contínuos de demissões e de novas contratações, com a disseminação, por exemplo, no decorrer dos anos 1990, dos Programas de Demissão Voluntária (PDV), buscam dar características não-traumáticas à "reestruturação" da subjetividade de classe. Ao que se visa com tais processos de "enxugamento" da força de trabalho é não apenas reduzir custos salariais, mas, principalmente, criar um campo de incorporação para nova força de trabalho mais disposta a apreender as novas habilidades cognitivas e comportamentais da produção capitalista. Nesse processo de reestruturação da subjetividade da força de trabalho torna-se necessário suprimir a memória do "trabalhador coletivo", ou seja, suas experiências de classe.

O "espírito do toyotismo" assumiu uma forma institucional nos anos 1990, principalmente através das novas políticas governamentais de formação profissional, levadas a cabo pelo Ministério do Trabalho e Ministério da Educação e Cultura, principalmente a partir do governo Cardoso (em 1994). Por exemplo, todo o discurso que embasou o Plano Nacional de Qualificação do Trabalhador (PLANFOR), sob o governo Cardoso, é intrinsecamente toyotista, contribuindo, em grande parte, para a difusão dos conceitos e da ideologia toyotista no Brasil (BATISTA, 2002).

$\mathrm{O}$ próprio conceito de novas competências, entendida como capacidade de diagnóstico e intervenção em tempo real, com a aquisição de todo um background de conhecimentos, tácitos ou formais, que o habilitam a fazer diagnósticos, propor soluções e tomar medidas em cadeia de decisões cada vez mais curtas, possui, como paradigma, a produção flexível toyotista.

Governo, escolas e sindicatos passaram a incorporar o discurso da nova pedagogia empresarial, articulando, por exemplo, em torno do conceito de "empregabilidade", as noções de competências e novas habilidades cognitivas e comportamentais necessárias para a nova produção capitalista. Constitui-se todo um complexo de aparelhos ideológicos privados e públicos que buscam disseminar, através de cursos e treinamentos, a "nova racionalidade" da produção capitalista sob a mundialização do capital, o que implica construção de uma nova linguagem e sintaxe das práticas do trabalho. Na verdade, o objetivo, em última instância, é capturar a subjetividade do trabalho e não apenas a consciência de classe (ALVES, 2001, p. 39).

Na década de 1990, o debate sobre o "modelo japonês" no Brasil tendeu a não ocupar tanto as discussões da sociologia do trabalho, em contraste com a década anterior, quando assumiu um caráter quase paradigmático, mobilizando argumentos, contra e a favor; de certo modo, a preocupação particular da ótica hegemônica na sociologia do trabalho no Brasil era salientar o "modelo japonês" e sua adaptação espúria à realidade brasileira (HIRATA, 1993, p. 139).

Entretanto, com o desenvolvimento do toyotismo sistêmico nos anos 1990, tendeu a disseminar-se uma literatura não-crítica e quase apologética do "novo modelo produtivo". O novo discurso produtivista ocultava o verdadeiro sentido da nova ideologia do toyotismo, isto é, reconstituir a exploração capitalista de acordo com as implicações objetivas e subjetivas do novo regime de acumulação flexível do capital, que articula, cada vez mais, trabalho material e trabalho imaterial e que busca, na esfera da inteligência coletiva e da cognição cooperativa, um novo lastro para a produção de valor.

O "espírito do toyotismo" determinou os termos do debate não apenas na sociologia do trabalho, mas nas áreas de educação e de serviço social. Surgiu toda uma discussão sobre as novas qualificações do trabalho, formação profissional, saberes e novas competências, ou seja, um complexo temático-ideológico com vínculos estruturais com a lógica do "toyotismo sistêmico" (CASALI et alii, 1997). A própria discussão sobre trabalho material e imaterial, que se desenvolveria na sociologia do trabalho de cariz marxista em 
meados da década passada, tendeu a ser meramente um desdobramento heurístico, mais elaborado, da problemática do toyotismo como ideologia orgânica da produção capitalista (voltada para a produção de uma nova subjetividade contingente de classe).

\section{b) Lógica toyotista e a síndrome do medo}

Se o "modelo japonês" sustentava-se em contrapartidas salariais e institucionais (a constituição de um mercado interno com perspectiva de carreira nas grandes empresas e emprego vitalício, por exemplo), o toyotismo que se constituiu como ideologia orgânica e universal da produção capitalista no decorrer dos anos 1990, tendeu a sustentar-se em contrapartidas de mercado, articulando o novo consentimento do trabalhador assalariado por meio de disposições anímicas regressivas.

A busca do consentimento ativo da subjetividade do "trabalho vivo" passou a constituirse, em última instância, através da síndrome do medo cujo substrato objetivo é dado pela constituição de um precário mundo do trabalho. Essa é, portanto, a função sócio-ontológica da nova precarização heteróclita sob a mundialização do capital: constituir o consentimento ativo necessário para o desenvolvimento dos nexos contingentes do toyotismo e produzir uma subjetividade regressiva, avessa às atitudes antagônicas de classe diante da lógica do capital.

Diante de um precário mundo do trabalho, a consciência contingente de operários e empregados tende a caracterizar-se pelo consentimento e acomodação diante das novas condições de exploração da força de trabalho instituídas pelo capital. O toyotismo passou a exigir uma disposição anímica de operários ou de empregados, sem contrapartidas salariais ou contratuais, talvez a mera concessão de bônus de produtividade.

A "socialização" do toyotismo tende a ser, sob a mundialização do capital, totalmente dessocializadora, debilitando a perspectiva (e a subjetividade) de classe (implicando, desse modo, uma "corrosão do caráter", conforme a expressão utilizada por Sennet em seu estudo seminal sobre o capitalismo flexível). Ela aparece, portanto, como o avesso da socialização do fordismo com sua promessa de "integração” (SENNET, 1998). Como verificamos no caso brasileiro, ela tende a atingir o "núcleo estruturado" do contingente de trabalhadores assalariados (aqueles detentores de direitos trabalhistas), ligados às grandes empresas e sua rede de subcontratação.

Além disso, no caso do capitalismo no Brasil, com sua via de objetivação colonial e hipertardia, com traços estruturais de desigualdade e exclusão social, a introdução da lógica toyotista, com seu lastro de racionalização do trabalho superior à da organização tayloristo-fordista, só tende a aprofundar, ainda mais, o contraste entre uma sociabilidade irracional exacerbada, que caracteriza os países capitalistas subalternos, e uma produção capitalista cada mais racionalizada.

A precarização heteróclita que se disseminou nos anos 1990 no Brasil e que atingiu o "núcleo moderno" da implicação assalariada, catalisando a síndrome do medo (que se tornou uma das principais variáveis psicossociais para a introdução do toyotismo sistêmico), tornou-se perceptível não apenas através do crescimento do desemprego de massa, mas, principalmente, pela tendência contínua de precarização do estatuto salarial da força de trabalho no Brasil.

Mesmo em períodos de crescimento relativo do emprego formal, como em 2000, evidenciouse a precarização do salariato no Brasil. Apesar do crescimento relativo do nível de emprego industrial em 2000 (com reflexos positivos no emprego formal no país), o nível de emprego era ainda $25 \%$ menor do que em julho de 1994, quando foi lançado o Plano Real. E embora tenha ocorrido o crescimento do emprego formal, a tendência de precarização da estrutura ocupacional mantevese em muitos aspectos, demonstrando a contínua precarização do estatuto salarial da força de trabalho no Brasil: "O que se pode concluir é que segmentos importantes da força de trabalho (adultos, chefes de família, pessoas com mais experiência de trabalho) estão perdendo espaço no emprego formal. Não obstante, jovens estão substituindo-os, com o maior grau de escolaridade típico dessa população, com remunerações menores e limitadas, em geral, ao teto de três salários mínimos" (A DETERIORAÇÃO DO EMPREGO, 2001).

A degradação do mundo do trabalho no Brasil nos anos 90 atingiu não apenas o setor privado da economia brasileira, mas também o setor público. Desde o governo Collor, e principalmente sob o governo Cardoso, a administração pública tornouse alvo das políticas neoliberais de desmonte do Estado. O corte dramático de investimento em custeio e contratação, buscando atingir um superávit primário capaz de satisfazer o FMI, 
prejudicou a qualidade do serviço público no país e degradou salários e condições de trabalho dos trabalhadores do setor público. Sob as políticas neoliberais, o Estado brasileiro deixou de ser indutor de políticas públicas e de investimentos sociais, cabendo a ele apenas as atividades de regulador e fiscalizador da iniciativa privada.

Alguns dados podem ilustrar a degradação do trabalho no setor público na década passada. Por exemplo, entre 1992 e 1995 o emprego público até cresceu, embora o crescimento tenha se dado abaixo da expansão da ocupação no país: a sua participação na ocupação reduziu-se, alcançando 11,4\%. Entretanto, entre 1995 e 1997, a partir do governo Cardoso, a queda do emprego público foi significativa, com menos 140000 empregos (antes das privatizações dos serviços públicos dos anos 1998 e 1999, quando a queda foi ainda maior) (EMPREGO PÚBLICO RESISTE, 2000).

Sob o governo Cardoso, o ajuste fiscal, a privatização e a reforma administrativa contribuíram para uma modificação substancial do papel do Estado brasileiro, com a ocupação no setor público perdendo importância no mercado de trabalho. Apesar disso, o setor público ainda é um importante empregador no país. Segundo levantamento do BNDES, com base no RAIS (Relação Anual das Informações Sociais), relativo a 2000, 25,3\% dos 28 milhões de empregos formais em todo o Brasil estão na administração pública. Entretanto, de 1992 a 1998, mudou o perfil do funcionário público no país, com a maior presença do servidor público sem vínculo empregatício estável. A porcentagem de servidores públicos regidos pela CLT caiu de 35,5\% em 1992, para 23,0\% em 1998; a de estatutários teve um pequeno aumento de $49,4 \%$ para $53,5 \%$ enquanto os outros tipos de vinculo empregatício, ou seja, temporários, teve um aumento significativo, de $11,7 \%$ para $19,7 \%$, o que demonstra um aspecto da precarização do trabalho no setor público na "década neoliberal" (PESSOA, 1999).

\section{III.2. O novo (e precário) mundo do trabalho}

$\mathrm{Na}$ "década neoliberal" surgiu uma nova configuração do mundo do trabalho no Brasil. Ela desenvolveu-se articulando as dimensões do "novo" e as do "precário" mundo do trabalho. O desenvolvimento do toyotismo sistêmico tendeu a acirrar o contraste entre formas "arcaicas" e "modernas" de exploração da força de trabalho. Por um lado, a constituição de um núcleo de novos operários e empregados ligados às corporações industriais e de serviços mais dinâmicas, e por outro lado, o desenvolvimento de uma precarização heteróclita da força de trabalho, que se caracteriza não apenas pelo desemprego de massas e pela inatividade, mas pela degradação de estatutos salariais e proliferação de trabalhos temporários, seja em atividades industriais ou de serviços.

\section{a) O novo proletariado industrial e de serviços}

A partir do novo complexo de reestruturação produtiva tendeu a ocorrer no core dos conglomerados industriais e de serviços, a constituição de um novo proletariado industrial e de serviços, um contingente mais restrito de jovens, homens e mulheres, com maior qualificação, que passaram a integrar o mundo da produção sob a égide da lógica organizacional (e ideológica) do toyotismo. Primeiro, são operários e empregados com maior qualificação. Por exemplo, no caso da categoria metalúrgica, tendeu-se a exigir, cada vez mais, domínio técnico e alto grau de escolaridade, ou seja, Ensino Médio, muitas vezes completo, e polivalência, isto é, aptidão para trabalhar em vários setores na linha de produção (é uma das disposições toyotistas que tende a significar tãosomente uma intensificação da exploração da força de trabalho). No caso do trabalhador bancário, em virtude da alteração de seu foco profissional, tornando-se ele um "vendedor de produtos" e não mais um "prestador de serviços", passou-se a exigir dele novas habilidades cognitivas e comportamentais.

Em termos relativos, o novo proletariado industrial e de serviços, com estatuto salarial formal, passou a ter uma maior estabilidade no emprego. Segundo dados da RAIS (de 1999), de 1994 a 1999 tendeu-se a aumentar o tempo médio de permanência no emprego entre os operários e empregados com carteira assinada (de 65,1 meses em 1994 para 66,3 meses em 1999).

Apesar disso, a característica estrutural do capitalismo hipertardio no Brasil, a superexploração da força de trabalho, não apenas persistiu, mas ampliou-se com o novo complexo de reestruturação produtiva, tendo em vista que o ganho de produtividade alcançado por uma força de trabalho mais qualificada e comprometida em executar, com mais intensidade, suas tarefas, não correspondeu a um aumento do salário real.

Na verdade, na "década neoliberal", a remuneração salarial não acompanhou o ganho de produtividade alcançado. De modo geral, acen- 
tuou-se a queda da participação dos salários no PIB, de $45 \%$ em 1990, para $37 \%$ em 1999, em contraste com o crescimento da produtividade da indústria, em média, 2,53\% no Brasil, de 1991 a 1998 (um detalhe: esse ritmo foi parecido ao da economia norte-americana sob a nova economia, cuja produtividade crescia $2,65 \%$ por ano desde 1995).

A nova geração de operários e empregados, aqueles com estatuto salarial formal e representando um contingente "nuclear" da força de trabalho, diante da constituição de um precário mundo do trabalho, tende a ter, como observa
Rodrigues no caso dos metalúrgicos do $\mathrm{ABC}$, "uma postura mais pragmática e mais realista na relação capital-trabalho". E salienta ele: "o medo do desemprego passa a ser a principal preocupação para um amplo setor da mão-de-obra" (RODRIGUES, 1997, p. 123; sem grifo no original). Na verdade, os jovens operários assumem uma atitude mais pró-ativa e colaborativa, apesar de incorporar uma consciência ativa de direitos e de participação sindical, ainda limitada pelo corporativismo de participação (no caso, os metalúrgicos do $\mathrm{ABC}$, principalmente das montadoras).

GRÁFICO 5 - Número de horas pagas, produção e produtividade (Brasil) (1990: base 100)

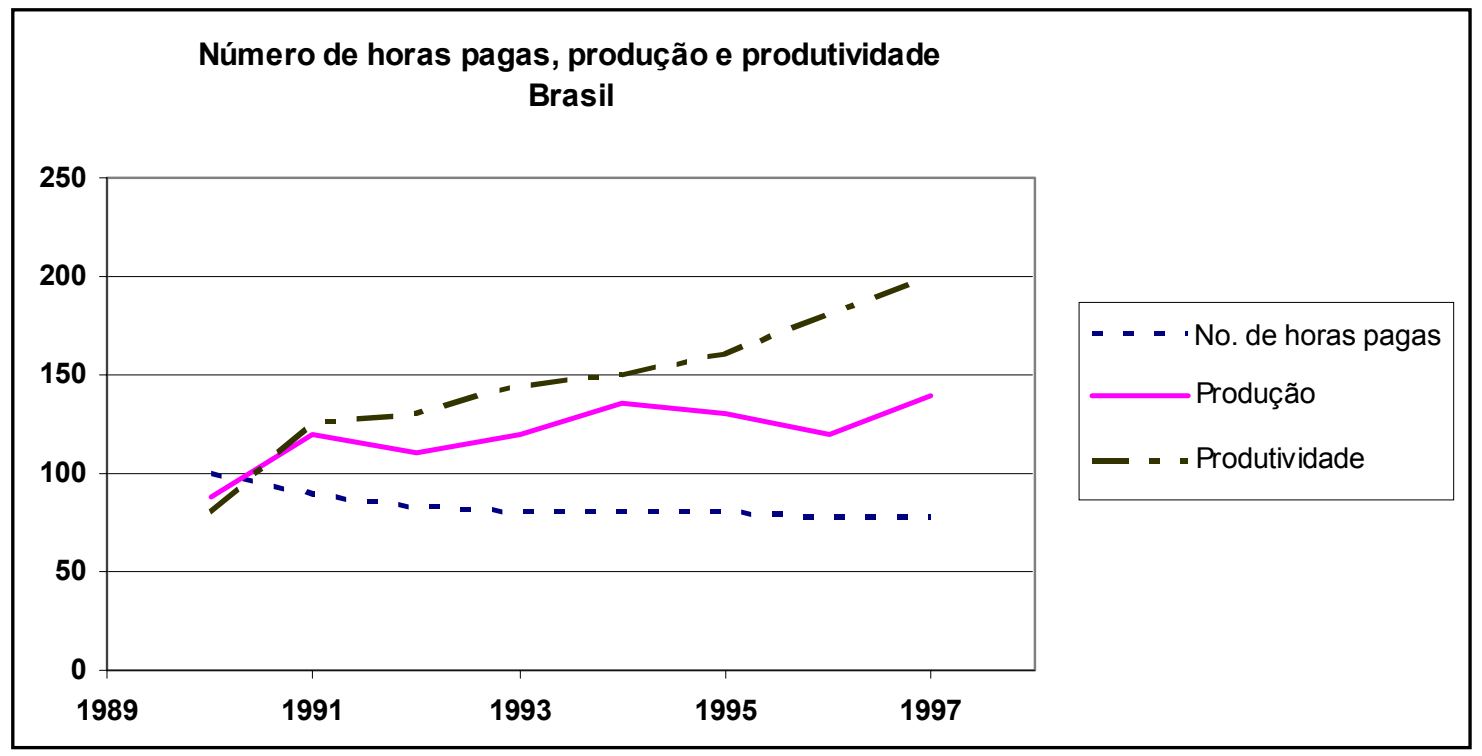

Fonte: IBGE, Pesquisa Industrial Mensal-Divisão Geral e Pesquisa Industrial Mensal-Produção Física (apud BONELLI \& FONSECA, 1998, p. 73).

\section{b) O precário mundo do trabalho}

Se, por um lado, é perceptível a constituição de um contingente restrito de novos operários e empregados ligados a conglomerados industriais e de serviços, com estatuto salarial formal, por outro lado, tendeu a ampliar-se o contingente do proletariado industrial e de serviços mais precário, constituído pela força de trabalho das suas redes de subcontratação. O crescimento exacerbado da terceirização na indústria e serviços contribuiu para a constituição ampliada do precário mundo do trabalho. A disseminação de cooperativas de trabalho, muitas delas constituídas para burlar a legislação trabalhista nas novas zonas industriais transplantadas da região Nordeste, são expressões dessa precarização heteróclita da força de trabalho no país (BUONFIGLIO, 1999).

Os crescimentos das empresas de trabalhos temporários e de trabalhadores domésticos demonstram a inserção crescente de um contingente maciço de jovens, homens e mulheres, no mercado de trabalho de maneira precária, vendendo sua força de trabalho para indústria, bancos e comércio por tempo parcial e determinado. Em sua maioria, pertencem ao contingente de trabalhadores ocupados do setor privado que não possuem cobertura da Previdência Social, ou seja, não têm direito à aposentadoria e nem auxílio-doença (segundo indicadores sociais de 2000, são cerca de 38,7 milhões de operários e empregados, ou seja, cerca de $60 \%$ dos trabalhadores ocupados do setor privado) (SISTEMA EXCLUI, 2000). 
É nesse contexto de uma precarização heteróclita da força de trabalho que podemos compreender o aumento da informalização nos anos 1990. Ele possui um complexo de determinações sociológicas que não nos cabe investigar aqui. $\mathrm{O}$ que iremos salientar é que ela é a expressão contingente da tendência de contínua precarização da força de trabalho no Brasil. Podemos explicar seu crescimento através de processos típicos da "década neoliberal", como, por exemplo, o novo complexo de reestruturação produtiva, que através da terceirização, contribuiu para o crescimento de pequenas e médias empresas nas redes de subcontratação. Com pequena margem de lucratividade e pressionadas pelos custos tributários e financeiros, algumas empresas subcontratadas das corporações industriais e de serviços tenderam a terceirizar e subcontratar força de trabalho sem carteira assinada (o aumento da presença de pequenas e médias empresas na década de 1990 acompanhou tal tendência).

Por outro lado, o aumento do comércio ambulante é um dado importante não apenas das regiões metropolitanas, mas das cidades médias no Brasil, aparecendo como uma atividade permanente ou imposta pelo mercado a um contingente de proletários desempregados, subempregados e migrantes de áreas rurais nos centros urbanos médios ou grandes (o problema da migração rural e do desemprego no campo adiciona novas determinações à precariedade do mundo do trabalho urbano). O comércio ambulante ou o trabalho por conta própria precarizada tende a expressar um desemprego oculto que acompanha o crescimento do desemprego aberto no Brasil.

\section{c) O crescimento do desemprego aberto}

A dimensão de precarização heteróclita articulase com o crescimento do desemprego, em suas várias dimensões (aberto ou oculto). No tocante à indústria, o Brasil registrou nos anos 1990 queda no nível de ocupação média anual de $1 \%$, quando nos anos 1980 havia registrado expansão média anual de 3,1\% - entramos no século XXI com menos emprego na indústria que a ocupação agropecuária. Se nos anos 1980, o desemprego cresceu a uma taxa média anual de $3,8 \%$, entre 1989 e 1999 o volume de desempregados cresceu a uma taxa média anual de $15,4 \%$, significando que a cada dois postos de trabalhos criados surgia mais um novo desempregado (POCHMANN, 2000b). Se em 1996 tínhamos 4,74 milhões de desempregados, em 1999 temos 7,23 milhões. No caso das regiões metropolitanas do país, o desemprego aumentou significativamente, de 9,5\% em 1996, para 14\% em 1999, principalmente nas regiões sul e sudeste (CAPITAIS PERDEM MAIS, 2000).

É claro que o desemprego no Brasil possui múltiplas determinações. Existem, por exemplo, desempregados urbanos (e rurais) de categorias assalariadas da indústria, dos serviços e da agricultura, atingidas pelo novo complexo de reestruturação produtiva, com seus processos de inovações (e racionalização) organizacionais e a adoção de novos padrões tecnológicos. No caso da indústria, destacamos que o complexo de reestruturação produtiva (com o toyotismo sistêmico) contribuíram para o aumento da produtividade do trabalho e a diminuição dos postos de trabalho.

O exemplo da indústria automobilística na região do $\mathrm{ABC}$ paulista é significativo. Em janeiro de 1990, os operários das montadoras na região perfaziam um total de 57939 , e diminuíram para 33877 em junho de 2000 (DIEESE, 2000). De 290 mil pessoas que perderam o emprego metalúrgico no ABC, no período de 1989 a 1997, só metade conseguiu retornar ao mercado de trabalho formal. Dos $50 \%$ que conseguiram emprego, $5 \%$ foram para o comércio, $10 \%$ para a área de serviço e $17 \%$ retornaram à indústria automobilística e $18 \%$ recolocaram-se em postos de trabalho do setor metalúrgico. Os outros $50 \%$ estão desempregados ou caíram na informalidade (CARDOSO, 2000, p. 65).

A perda de postos de trabalho atingiu vários setores industriais: por exemplo, o setor do aço possuía em 1996, cerca de 65227 trabalhadores; em 2000, esse número caiu para 50365 trabalhadores, mesmo tendo verificado aumento da produção. É claro que o desemprego cresceu em setores da indústria e dos serviços atingidos pelo desmonte de cadeias produtivas em virtude da perda de mercado, decorrente da abertura comercial. A redução das tarifas de $50 \%$ em média e as baixas taxas de juros externas favoreceram as importações de produtos prontos para o consumo, em prejuízo da produção interna, com reflexos diretos no emprego formal brasileiro. 
GRÁFICO 6 - Taxa média anual de desemprego aberto (Brasil)

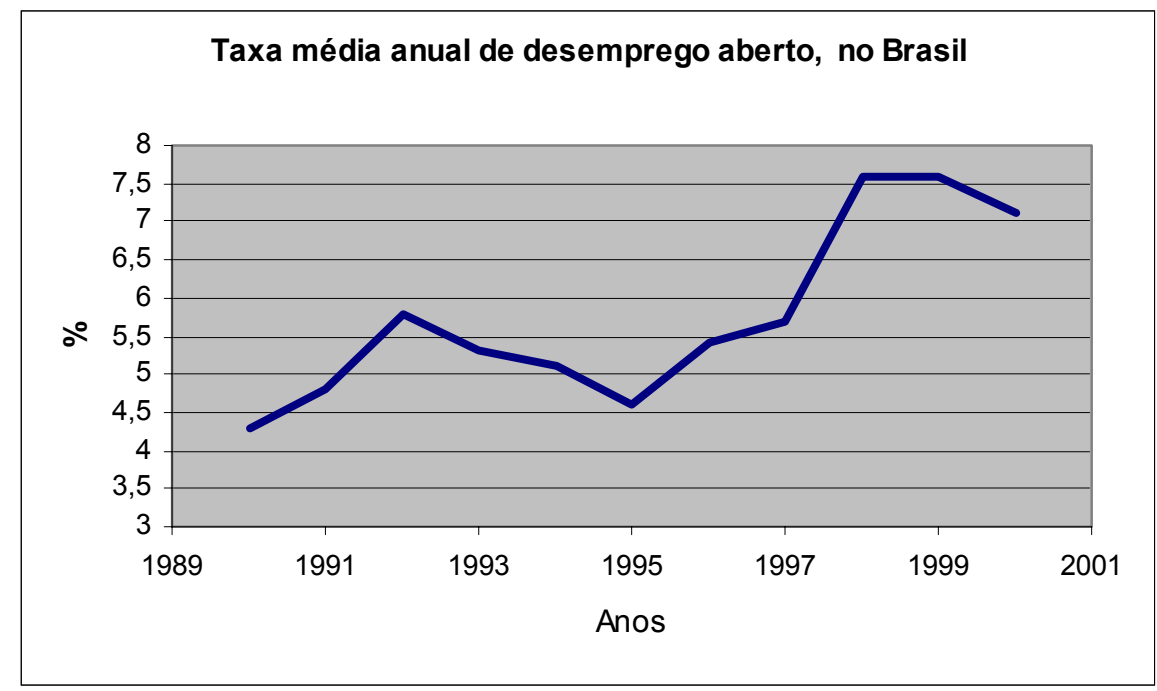

Fonte: IBGE (2001b, p. 51).

No caso da agricultura, entre 1989 e 1999, ocorreu a desaceleração da redução na ocupação agropecuária $(-0,8 \%)$, frente à diminuição verificada entre 1979 a 1989 (-28,9\%). Entretanto, o desemprego tecnológico cresceu em algumas culturas e regiões em virtude da mecanização em regiões de agroindústria desenvolvida, como no estado de São Paulo (CAMARGO \& MARTINELLI JR., 1997, p. 132). Mas isso não significa que a população rural tenha diminuído. Pelo contrário, o mundo do trabalho rural tornou-se mais complexo e diversificado. A divisão entre campo e cidade tornou-se cada vez mais relativa em virtude do desenvolvimento ampliado do capitalismo nas atividades rurais.

Segundo dados do Projeto Rurbano, desenvolvido por José Graziano da Silva, de 1992 a 1999, apesar de o emprego agrícola ter tido redução de $1,7 \%$ ao ano (maior do que na década de 1980 , que era de $0,4 \%$ ao ano), a população rural passou a crescer $0,2 \%$, aumentando, portanto, o emprego não-agrícola (as famílias rurais passaram a abandonar atividade agrícola, tendo ocupações em serviços domésticos, ajudantes, balconistas, pedreiros etc.). Portanto, o mundo do trabalho no campo tendeu a incorporar atividades não-agrícolas e de prestação de serviços (SILVA, 1999).

O desemprego no Brasil da "década neoliberal" tendeu a atingir contingentes crescentes de força de trabalho jovem, ou seja, atingiu aqueles que buscam o primeiro emprego. Na década passada, o país criou apenas 100 mil postos de trabalho para jovens, enquanto 2,8 milhões de jovens ingres- saram no mercado de trabalho. Dos 3,2 milhões de empregos formais destruídos, 2 milhões atingiram o segmento com menos de 25 anos (POCHMANN, 2000a). O subgrupo populacional que vai dos 18 aos 24 anos, embora mais qualificado, tendeu a enfrentar maiores dificuldades no mercado de trabalho: comparados com a de outros grupos etários, a taxa de desemprego entre os jovens é relativamente alta, chegando a $15 \%$, enquanto na faixa dos 40 anos a 49 anos, não ultrapassa 5\%. O desemprego entre os jovens passou de 1 milhão em 1989, para 3,3 milhões em 1998 (A ADOLESCÊNCIA PROLONGADA, 2000).

\section{d) Os proletários assalariados e por conta própria nas atividades de serviço}

No bojo do novo (e precário) mundo do trabalho é importante destacar o crescimento relativo dos trabalhadores assalariados (e por conta própria) das atividades de serviços. Por meio de indicadores do IBGE, podemos constatar que nos anos 1990 a expansão do setor terciário $(11,3 \%)$ não conseguiu ser superior à dos anos 1980 (21,7\%). Com certeza, a queda significativa da ocupação na administração pública, em relação à década passada, contribuiu para a redução relativa da expansão da ocupacional no setor terciário. Os segmentos ocupacionais do setor terciário que mais se destacaram nos anos 1990 foi o comércio $(3 \%)$, social $(2,9 \%)$ e prestação de serviço $(2,7 \%)$.

Mas o que se destaca, em relação aos anos 1980, é a posição do segmento ocupacional da 
prestação de serviços. De certo modo, o crescimento da ocupação de assalariados de prestação de serviços diz respeito à dinâmica da produção industrial, que passou a incorporar novas tecnologias microele-trônicas, exigindo, cada vez mais, serviços de pesquisa e desenvolvimento, de manutenção e assistência técnica, logística de produção etc. A terceirização, que é parte do novo complexo de reestruturação produtiva, atingiu as indústrias, tornando-as mais segmentadas e diferenciadas em si. Ocorreu a terceirização de atividades de serviços que, por serem endógenas à empresa industrial, tendiam, antes, a serem consideradas atividade industrial propriamente dita. Além disso, a privatização dos serviços de telecomunicações no Brasil e investimentos no setor de tecnologia de informação contribuiu para o crescimento dos postos de trabalho nas áreas de serviços de tele-comunicações e informação, que cresceram vin-culados à nova dinâmica industrial, principalmente no período de 19941997.

A nova dinâmica industrial, ligada à incorporação crescente de novas tecnologias de informação, exigiu profissionais assalariados qualificados capazes de executar cada vez mais atividades de trabalho imaterial, muitas delas vinculadas, direta ou indiretamente, à atividade industrial, mas tidas como serviços. É importante salientar que o mundo do trabalho de serviços assalariados possui tanto sua dimensão "nova", ligada à nova economia e a indústrias mais modernas, e uma dimensão tradicional e até precária, lícita ou ilícita, vinculada a atividades de prestação de serviço de menor valor agregado.

Além disso, no decorrer da "década neoliberal", por conta da reprodução social, cresceu a necessidade de investimentos nas áreas de educação e saúde. O desmonte do Estado e dos serviços públicos tendeu a abrir espaço de exploração para o capital nas áreas de prestação de serviço, principalmente educação (com a proliferação do ensino privado, que articula um contingente maciço de proletários da educação) e da saúde (com a disseminação dos planos privados de saúde), além de abrir espaço crescente para organizações não-governamentais e cooperativas de trabalho, um crescente "terceiro setor", que passou a incorporar um contingente maciço de profissionais ao mundo do trabalho.

Os indicadores sociais não conseguiram incluir o crescimento do complexo de negócios ilícitos de serviços, nas áreas do tráfico de drogas, de armas etc. Uma massa de capital não desprezível mobiliza para a atividade ilícita um contingente de trabalhadores do crime, recrutados entre desempregados e proletários "excluídos". Por exemplo, segundo o Mapa da Inclusão/Exclusão Social 2000, ao longo da década de 1990 a exclusão social aumentou na cidade de São Paulo, um dos centros urbanos industriais mais desenvolvidos do país: dos 96 distritos que compõem a cidade, 53 tiveram uma piora significativa nas condições de vida de seus habitantes, 6 ficaram praticamente estáveis e apenas 37 registraram melhoras (TOLEDO \& ALENCAR, 2000). A presença do "crime organizado" cresceu e vicejou diante da mercantilização exacerbada das relações sociais e do desmonte do poder público. Em geral, os negócios do crime organizado e o complexo de proletários do ilícito que mobiliza tende a não ser incorporado nas estatísticas sociais da informalização.

Finalmente, o desenvolvimento da precarização heteróclita contribuiu, de certo modo, para o crescimento do contingente de mulheres na PEA. Ele diz respeito não apenas a uma suposta modernização social, com as mulheres tornando-se independentes em termos financeiros, mas principalmente é indicativo do crescimento do desemprego masculino, do crescimento das mulheres como chefes de família ou ainda como parceiras de renda familiar (portanto, sintoma da desagregação da concepção clássica de "família" ou do decréscimo da renda familiar, respectivamente). Além disso, é expressão da precarização heteróclita da força de trabalho no Brasil, tendo em vista que, mesmo inserida no mercado formal de trabalho, a mulher é segregada, ganhando menos que os homens (a "segregação por gênero").

A maior concentração de mulheres é no mercado informal, sobretudo no trabalho doméstico. Por exemplo, do total de trabalhadores abrangidos pela RAIS, que atinge o mercado formal de trabalho, as mulheres ocupam, com dados de 1997, apenas 38\% dos empregos, num total de 9,1 milhões de trabalhadores em vários setores (serviços, administração pública, comércio, indústria de transformação e outros). Uma peculiaridade é que a maioria das mulheres trabalha em empresas de pequeno porte, principalmente do setor de comércio (exceto no setor de administração pública). Entretanto, até mesmo no mercado formal, a mulher ganha menos que o homem 


\section{(MERCADO FORMAL, 2000).}

\section{III.3. A fragmentação de classe e crise do sindi- calismo no Brasil}

No decorrer da "década neoliberal" ocorreu uma "implosão" dos núcleos mais organizados da classe, com importantes categorias de operários e empregados organizados tornando-se objeto de uma nova ofensiva do capital na produção. É o caso, por exemplo, das categorias de metalúrgicos e bancários, que se destacaram nos anos 1980 como vanguardas da resistência sindical. As bases sindicais de tais contingentes de trabalhadores assalariados, categorias importantes para a dinâmica da luta de classes no país, tiveram no decorrer dos anos 1990 perdas significativas de postos de trabalho, seja devido à nova ofensiva do capital na produção, seja devido à política neoliberal (ALVES, 1995, p. 109).

$\mathrm{Na}$ verdade, não é que a classe tenha se fragmentado, no sentido empírico, apesar de que o mundo do trabalho tenha assumido, em termos objetivos, uma feição mais heteróclita e segmentada, ressaltando os contrastes ocupacionais, profissionais e de qualificação. O que ocorreu foi a dispersão de seus coletivos organizados, bases sindicais militantes e organizações por local de trabalho, possuidores de uma experiência de luta de classes, constituídas no decorrer dos anos 1980. Mesmo no setor público, onde a ofensiva do capital (na forma da política neoliberal) assumiu a forma de privatização, desmonte e precarização das condições de trabalho e do estatuto salarial, o potencial de mobilização e luta sindical, apesar de vigoroso em algumas categorias mais organizadas, não conseguiu ter a mesma eficácia do movimento sindical da década passada.

Ora, o novo complexo de reestruturação produtiva (e os ajustes neoliberais) tiveram seu caráter político (e ideológico) desvelado no decorrer dos anos 1990. Seu movimento objetivo de exploração da força de trabalho e de acumulação de capital, principalmente no núcleo do trabalho produtivo, pressupunha a debilitação relativa da objetividade (e subjetividade) da classe.

As sucessivas conjunturas de flutuação na atividade da economia brasileira na "década neoliberal", o complexo de reestruturação produtiva (cuja expressão mais significativa nos anos 1990 foi a terceirização) com seu impacto abrupto no mundo do trabalho organizado, conseguiram promover uma fragmentação objetiva dos núcleos mais organizados da classe, expondo sua fragmentação subjetiva (e política). Os limites estruturais do sindicalismo e a debilidade política (e ideológica) do partido de classe tornaram-se manifesta. Os sindicatos demonstraram sua dificuldade histórica de lidar com o precário mundo do trabalho, com o trabalho precarizado, parcelado e informal, instalado na maioria das vezes nas pequenas e médias empresas e nos domicílios.

No tocante à práxis sindical dos anos 1990 , constatamos o predomínio de uma nova burocracia sindical, representada, no campo da esquerda social-democrata, pela CUT, e no campo da direita, pela Força Sindical, que passaram a incorporar práticas sindicais defensivistas de novo tipo, buscando resistir, de modo propositivo (ou de adesão sistemática, como é o caso da Força Sindical), à ofensiva neoliberal (BOITO, 1999, p. 186).

Desde meados dos anos 1980 são perceptíveis tendências de um sindicalismo de novo tipo que se desenvolvia, por exemplo, no seio da CUT, com o predomínio de um sindicalismo propositivo e de participação, de cariz social-democrata, ou ainda, o surgimento de uma alternativa liberalconservadora, a Força Sindical, em 1991.

De certo modo, a irrupção da "década neoliberal", com a derrota política da Frente Brasil Popular, em 1989, e o desenvolvimento sistêmico de um novo regime de acumulação flexível, sob o primado do toyotismo como nova ideologia orgânica da produção capitalista, além do débâcle do "socialismo real" (com a implosão do bloco soviético, a queda do Muro de Berlim e o desaparecimento da URSS) e do clima políticoideológico pró-capitalista (a exuberância da ideologia da globalização sob a hegemonia americanista) contribuíram para a consolidação política de tendências moderadas e defensivista no seio do sindicalismo cutista e para o surgimento de tendências liberais no sindicalismo brasileiro (a criação da Força Sindical ocorreu em 1991, num contexto de reação política no país). Na verdade, criou-se um caldo sindical defensivista de novo tipo, capaz de garantir a sobrevivência de bases sindicais e de seus aparatos burocráticos sob a ofensiva do capital (de práticas de resistência passou-se à formulação de novas estratégias sindicais e políticas) (ALVES, 2000, p. 302).

Desenvolveu-se nos anos 1990 uma crise do sindicalismo no Brasil e não propriamente uma crise sindical, tendo em vista que as burocracias sindicais têm conseguido, de certo modo, preservar a estrutura sindical vigente. A crise do sindicalismo 
caracteriza-se não apenas pela queda na taxa de sindicalização, mas principalmente pela diminuição da eficácia da ação sindical.

$\mathrm{Na}$ verdade, a ação sindical, principalmente aquela vinculada ao novo sindicalismo dos anos 80 , tende a perder sua dimensão política, de prática de classe de cariz antagonista diante do capital, assumindo um caráter pragmático-neocorporativista, mais circunscrito à segmentação setorial ou por empresa (RODRIGUES, 1999).

Em primeiro lugar, no decorrer dos anos 1990 tendeu a crescer a participação do Poder Judiciário nas relações trabalhistas, haja vista que tanto trabalhadores individuais quanto sindicatos com menor capacidade de atuação tenderam a transferir o palco das negociações para a Justiça do Trabalho (num contexto político de ofensiva neoliberal pela desregulamentação da legislação trabalhista e esvaziamento normativo da Justiça do Trabalho).

Em segundo lugar, cabe salientar a descentralização das negociações coletivas, principalmente a partir do Plano Real e da estabilização monetária, em 1994. Sob a ameaça constante do desemprego e da precarização persistente, o sindicalismo brasileiro, em seus pólos mais desenvolvidos, tendeu a evitar, ou tornou-se incapaz de realizar, greves gerais por categoria, predominando, sob pressão do capital, negociações coletivas descentralizadas e por empresa (GALVÃO, 1999). Afirmou-se uma tendência, que vinha desde meados dos anos 1980, ou seja, de predomínio das negociações coletivas e greves por empresa (são exceções, por exemplo, a greve dos petroleiros em 1995 que assumiu, de certo modo, um caráter político contra a política neoliberal do governo Cardoso).

A escassez das greves gerais por categoria na década passada - expressa, por exemplo, no decréscimo da média de grevistas por greve, apesar do incremento relativo da quantidade de greves (conforme Tabela 1) -, além de demonstrar um sintoma das dificuldades de mobilização sindical nas condições adversas de um precário mundo do trabalho, significou o esgotamento relativo do instrumento político de generalização das lutas da classe num contexto de política neoliberal, ofensiva do capital na produção e da constituição de um novo mundo do trabalho. Além disso, representa, é claro, uma debilidade política (e ideológica) das organizações sindicais e da sua capacidade de reagir à ofensiva do capital sob as condições objetivas de um novo regime de acumulação capitalista.

TABELA 1 - Número de greves, grevistas e média de trabalhadores por greve (1992-1997)

\begin{tabular}{|c|c|c|c|}
\hline Anos & Greves & Grevistas & $\begin{array}{c}\text { Média de grevistas por } \\
\text { greve }\end{array}$ \\
\hline 1992 & 557 & 2562385 & 4600 \\
\hline 1993 & 653 & 3595770 & 5507 \\
\hline 1994 & 1034 & 2755619 & 2665 \\
\hline 1995 & 1056 & 2277894 & 2157 \\
\hline 1996 & 1258 & 2534960 & 2015 \\
\hline 1997 & 630 & 808925 & 1284 \\
\hline
\end{tabular}

Fonte: DIEESE apud Pessanha e Morel (1999, p. 33).

Existe uma determinação reflexiva entre a política de descentralização das negociações coletivas e o desenvolvimento, nos anos 1990, de um toyotismo sistêmico, como "momento predominante" do novo complexo de reestruturação produtiva. O toyotismo representa, como salientamos, não apenas um mero novo modelo produtivo em si, mas uma nova ideologia orgânica da produção capitalista adequada às condições de crise do sistema sócio-metabólico do capital. Sua instauração sistêmica pressupõe a derrota política (e ideológica) dos "intelectuais orgânicos" da classe (sindicatos classistas e partido) - o que ocorreu, de fato, no decorrer da década de 1980 - e nos anos 1990 - nos principais países capitalistas, por conta da ofensiva do capital na produção e das políticas de neoliberalismo selvagem à la Thatcher. Foi nesse contexto depressivo de militância antagonista à lógica do capital que tenderam a predominar as políticas do sindicalismo propositivo de cariz neocorporativo e de participação.

Em terceiro lugar, no decorrer da "década neoliberal" tendeu a ocorrer uma maior participação dos sindicatos nos fóruns de políticas públicas e fóruns tripartites de discussão sobre capacitação 
tecnológica e de qualificação profissional, demonstrando uma maior preocupação dos sindicatos em interferir na definição de políticas públicas de maior alcance. É um sintoma de crise do sindicalismo, que, diante da diminuição da eficácia de ação sindical e incapaz de ir além da esfera econômico-corporativa dada pela estrutura sindical brasileira de cariz verticalista, busca dar sentido à sua prática política, intervindo em instâncias da burocracia pública e estatal.

Além disso, o acesso das centrais sindicais (CUT, CGT e Força Sindical) a fundos públicoestatais, como o FAT (Fundo de Amparo do Trabalhador), por meio de elaboração de projetos de qualificação profissional de acordo com a lógica do toyotismo sistêmico, tendeu a contribuir para a preservação da burocracia sindical num contexto de crise do sindicalismo (em 2000, a Força Sindical, por exemplo, consumiu $40 \%$ das verbas do FAT).

É claro que o sindicalismo no Brasil, apesar da "década neoliberal", preservou algum poder de barganha, alguma capacidade de reagir e de negociar, entretanto sem conseguir ir além da lógica concertativo-propositiva e sua implicação econômico-corporativa. Mesmo o maior experimento de resistência sindical dos anos 1990, a criação das câmaras setoriais durante o governo Collor, padeceu do viés neocorporativo, com cada sindi-cato levando a buscar soluções para o seu "setor", contribuindo para uma luta velada entre sindicatos de diferentes categorias e até entre a mesma ca-tegoria por verbas públicas para sua empresa ou setor, alimentando um exclusivismo ou egoísmo de fração (BOITO JR., 1999).

Durante o governo Cardoso, de 1994 a 2000, algumas categorias industriais mais organizadas e com maior poder de barganha sindical, de setores que registraram em determinados períodos da conjuntura, crescimento da produção e do emprego, conseguiram pequenos aumentos reais de salário. Por exemplo, em 1999, cerca de 35\% dos acordos coletivos concederam reajustes acima da inflação e em 2000, o percentual subiu para cerca de 56\% (após a desvalorização do Real, em 2000, o Brasil teve uma pequena retomada do crescimento da economia).

O que se observa é que os salários maiores tenderam a puxar a recuperação da massa salarial, demonstrando o foco restritivo e concentrador da reposição salarial no interior da classe, alimentando, portanto, tendências neocorporativas de parti- cipação. Se quem ganhava acima de vinte salários mínimos teve até $41 \%$ de reposição no salário, quem ganhava cinco salários mínimos teve, pelo contrário, 7,2 \% de queda no salário (RODÍZIO DE TRABALHADORES, 2001).

Se por um lado a renda salarial, no período curto de crescimento (1999-2000), recuperou-se em termos relativos, por outro lado a ocupação de contingentes maciços da classe continuou precária. A capacidade de barganha sindical tornouse um diferencial importante, contribuindo para a segmentação neocorporativa, por setor ou por empresa, no interior da classe. Na perspectiva da classe, observou-se uma dualidade relativa entre trabalhadores empregados, com maior poder de barganha sindical, que em períodos de crescimento recompõe perdas e ganhos salariais através de negociações por empresas, tendo participação em lucros e resultados; e um contingente crescente de trabalhadores precários de menor salário, não organizados em sindicatos e cuja capacidade de pressão coletiva é minada pelo desemprego maciço e pela debilidade organizativa crônica.

Para as categorias de assalariados mais organizados, a pauta de negociação coletiva tendeu a incorporar, por exemplo, a defesa do emprego, a Participação nos Lucros e Resultados (PLR), a flexibilização da jornada de trabalho (banco de horas) e a discussão na gestão e organização do trabalho. Na verdade, alteraram-se as implicações do processo de negociação coletiva, que passou a incorporar disposições do toyotismo sistêmico, ou seja, o foco político-territorial de antagonismo entre capital e trabalho circunscreveu-se ao âmbito da empresa e a implicação salarial vinculou-se mais a recompensas de desempenho individual ou em equipe.

Diante de um precário mundo do trabalho, de uma precarização heteróclita, com o desemprego tornando-se o espectro regressivo alimentador do medo de um "núcleo restrito" de trabalhadores industriais e de serviços empregados, o aumento nos valores da participação em lucros e resultados, para categorias de assalariados mais organizados, contribuiu não apenas para promover um envolvimento estimulado com os objetivos da empresa, mas para amortecer a rebeldia individual e coletiva diante de uma crescente superexploração da força de trabalho ${ }^{4}$.

4 A intensificação das tarefas e o aumento da produtividade 
A tendência de flexibilização da legislação trabalhista que ocorreu nos anos 1990 tendeu a incorporar as novas disposições do toyotismo sistêmico, institucionalizando a fragmentação de classe, principalmente em seu foco de negociação coletiva. A luta política (e ideológica) no seio do movimento sindical brasileiro tornou-se mais acirrada na "década neoliberal" por conta da tentativa do governo Cardoso e de lideranças sindicais de orientação neoliberal, ligadas principalmente à Força Sindical, em implementarem, sob oposição da CUT, uma política de desregulamentação do mercado de trabalho e de desmonte da CLT (Consolidação das Leis do Trabalho) como solução para a crise do emprego no país (o exemplo foi o projeto de lei que visava a estabelecer o Contrato de Trabalho por Tempo Determinado em 1997).

O que ocorre no Brasil dos anos 1990 é a expressão particular-concreta de uma ofensiva mundial do capital financeiro, de cunho político (e ideológico), que visa a degradar a base institucional de exploração da força de trabalho nos pólos mais organizados da classe trabalhadora, seja nos países capitalistas centrais (principalmente União Européia, onde o sindicalismo reserva ainda uma eficácia política), seja nos países capitalistas industrializados não-desenvolvidos (caso do Brasil).

A perspectiva do establishment liberal está expressa nas idéias do Prêmio Nobel de Economia em 2000, James Heckman, que sugere que: 1) os contratos de trabalho coletivos ou mesmo individuais sejam por empresa e não mais por categoria ou sindicato; 2) os contratos de trabalho temporário livremente negociados sejam em meses ou anos ou simplesmente pelo prazo da execução de um projeto, uma obra, uma encomenda, uma safra ou um negócio sazonal, e 3) a participação seja não apenas nos resultados (estimulado pelo contrato por empresa), mas na parte do prejuízo (BETING, 2000).

$\mathrm{Na}$ verdade, a implicação contratual descentralizada, por empresa, tende a debilitar a capacidade de resistência de classe e limitar a ação sindical a um campo econômico-corporativo. Diante da voracidade da reestruturação capitalista, o fato tende a tornar-se lei. O positivismo jurídico

do trabalho muito acima dos aumentos salariais demonstram um aprofundamento da superexploração do trabalho nos anos 1990. toma de assalto o Direito do Trabalho. A "velha" CLT tende a tornar-se um anacronismo jurídico. A lógica jurídica, subsumindo-se meramente à lógica do capital, tende a abolir a própria base ontológica do Direito do Trabalho, que se interverte em Direito Civil (VIANA, 1999, p. 15).

Mesmo diante de um novo (e precário) mundo do trabalho tenderam a disseminar-se novos (e velhos) movimentos de resistência social, de contingentes da classe trabalhadora, operários e empregados, e de contingentes excluídos da produção capitalistas (BUONFIGLIO, 2001). Entretanto, ainda representam movimentos sociais limitados (e fragmentários), alguns de caráter problemático - na perspectiva de representar uma alternativa à lógica mercantil-capitalista (como o movimento de cooperativas e de experiências autogestionárias), e outros, com maior expressão política (e social) e voltado para a crítica da "nova ordem neoliberal", como, por exemplo, o Movimento dos Trabalhadores Rurais Sem-Terra (MST), que traduz, em sua experiência de luta pela reforma agrária no país, as reivindicações de um contingente ampliado de proletários excluídos (ANTUNES, 1998).

De certo modo, o maior desafio do sindicalismo no Brasil na virada para o século XXI é romper com o viés burocrático-corporativo, organizar e mobilizar um contingente maciço de jovens operários e operárias, empregados e empregadas $\mathrm{e}$, inclusive, trabalhadores por conta própria precarizados, explorados pelo capital. Em decorrência da crise do sindicalismo, que possui um componente estrutural (os limites do sindicalismo diante da nova lógica de acumulação capitalista), a capacidade de agitação sindical no sentido de sua inserção nas lutas sociais tornouse bastante exígua (o próprio viés neocorporativo contribuiu para seu isolamento relativo dos problemas prementes do mundo do trabalho). Os sindicatos parecem incapazes de representar, não apenas em virtude de problemas burocráticoorganizativos (ainda bastante verticalizados), mas principalmente político-ideológicos, o novo (e precário) mundo do trabalho que surge com a mundialização do capital.

A “década neoliberal" representou a ampliação do vácuo organizativo do mundo do trabalho no Brasil. É claro que o sindicalismo brasileiro sempre organizou um contingente limitado do mundo do trabalho, restringindo-se, no caso de centros urbanos, aos núcleos modernos da produção capitalista no país. Mas, com a ofensiva do capital na produ- 
ção, que atinge os pólos mais desenvolvidos e organizados da força de trabalho, o sindicalismo foi atingido em sua base social moderna - o que significou uma regressão relativa do sindicalismo no Brasil, principalmente no tocante à sua capacidade de agitação social e de militância política.

Giovanni Alves (giovanni.alves@uol.com.br) é Doutor em Ciências Sociais pela Universidade Estadual de Campinas (UNICAMP) e Professor do Departamento de Sociologia e Antropologia da Universidade Estadual Paulista (UNESP), campus de Marília.

\section{REFERÊNCIAS BIBLIOGRÁFICAS}

ALMEIDA, M. H. T. 1996. Crise econômica e interesses organizados : o sindicalismo no Brasil dos anos 80. São Paulo : Edusp.

ALVES, G. 1995. Nova ofensiva do capital, crise do sindicalismo e as perspectivas do trabalho - o Brasil nos anos noventa. In : TEIXEIRA, F. J. S. \& OLIVEIRA, M. A. (orgs.). Neoliberalismo e reestruturação produtiva : as novas determinações do mundo do trabalho. São Paulo : Cortez.

1999. Trabalho e mundialização do capital : a nova degradação do trabalho na era da globalização. Londrina : Práxis.

2000. O novo (e precário) mundo do trabalho : reestruturação produtiva e crise do sindicalismo. São Paulo : Boitempo.

. 2001. Dimensões da globalização: o capital e suas contradições. Londrina : Práxis.

ANTONELLI, C. 1988. The Emergence of the Network Firm. In : (ed.). New Information Technology and the Industrial Change : the Italian Case. Dordrecht : Kluwer Academic Publishers.

ANTUNES, R. 1991. O novo sindicalismo. São Paulo : Brasil Urgente.

. 1998. Lutas sociais e desenho societal no Brasil dos anos 90. Crítica Marxista, Campinas, n. 7, p. 89-110.

.1999. Os sentidos do trabalho : ensaios sobre a afirmação e a negação do trabalho. São Paulo : Boitempo.

ARAÚJO, A. M. C., CARTONi, D. M. \& JUSTO, C. D. M. 1999. Reestruturação produtiva e negociação coletiva: a experiência recente dos sindicatos dos metalúrgicos, dos químicos e dos bancários de Campinas. Artigo apresentado no XXIII Encontro da Associação Nacional de Pós-Graduação e Pesquisa em Ciências Sociais, realizado de 19 a 23 de outubro de 1999, em Caxambu, Minas Gerais. Digit.

ARBIX, G. \& ZILBOVICIUS, M. (org.). 1997. De $J K$ a $F H C$ : a reinvenção dos carros. São Paulo : Scritta.

BATISTA JR., P. N. 2000. A economia como ela é... São Paulo : Boitempo.

BATISTA, R. L. 2002. A educação profissional na década neoliberal : o caso do PLANFOR. Marília. Dissertação (Mestrado em Ciências Sociais). Faculdade de Filosofia e Ciências, Universidade Estadual Paulista.

BETING, J. 2000. O futuro do emprego. O Estado de São Paulo, 14.out.

BIHR, A. 1998. Da grande noite à alternativa : o movimento europeu em crise. São Paulo : Boitempo.

BIONDI, A. 1999. O Brasil privatizado : um balanço do desmonte do Estado. São Paulo : Fundação Perseu Abramo.

2000. O Brasil privatizado II : o assalto das privatizações continua. São Paulo : Fundação Perseu Abramo.

BNDES. 1990. Diretrizes gerais para a Política Industrial e de Comércio Exterior (PICE). Rio de Janeiro : Banco Nacional de Desenvolvimento Econômico e Social.

BOITO JR., A. 1999. Politica neoliberal e sindicalismo no Brasil. São Paulo : Xamã.

BONELLI, R. \& FONSECA, R. 1998. Ganhos de produtividade e de eficiencia : novos resultados para a economia brasileira. Texto para discussão n. 557. Rio de Janeiro : Instituto de Pesquisas Econômicas Aplicadas. 
BUONFIGLIO, M. C. 2001. Dilemas do trabalho no final do século XX : desemprego e precarização. In : HORTA, C. R. H \& CARVALHO, R. A. A. (orgs.). Globalização, trabalho e desemprego : um enfoque internacional. Belo Horizonte : C/Arte.

CAMARGO, J. M. \& MARTINELLI JR., O. 1997. Relações de trabalho e a ocupação agrícola em São Paulo. Cadernos da FFC, Marília, v. 6, n. 1, p. 191-206, $2^{\circ}$ semestre.

CARDOSO, A. M. 2000. Trabalhar, verbo transitivo. Destinos profissionais dos deserdados da indústria automobilística. Rio de Janeiro : Fundação Getúlio Vargas.

CASALI, A., RIOS, I., TEIXEIRA, J. E. \& CORTELLA, M. S. (orgs.). 1997. Empregabilidade e educação : novos caminhos no mundo do trabalho. São Paulo : Pontifícia Universidade Católica de São Paulo.

CASTRO, N. A. (org.). 1995. A máquina e o equilibrista : inovações na indústria automobilística brasileira. Rio de Janeiro : Paz e Terra.

CHESNAIS, F. 1996. A mundialização do capital. São Paulo : Xamã.

DIEESE. 2000. Anuário estatístico. São Bernardo do Campo : Departamento Intersindical de Estudos Estatísticos e Sócio-econômicosSubseção ABC.

2002. A situação do trabalho no Brasil : um balanço dos anos 90. São Paulo : Departamento Intersindical de Estudos Estatísticos e Sócio-econômicos - Subseção ABC.

DRUCK, M. G. 1999. Terceirização : (des)fordizando a fábrica : um estudo do complexo petroquímico. São Paulo : Boitempo.

FILGUEIRAS, L. 2000. História do Plano Real : fundamentos, impactos e contradições. São Paulo : Boitempo.

GALVÃO, A. 1999. Participação e fragmentação : a prática sindical dos metalúrgicos do $\mathrm{ABC}$ nos anos 90. Campinas. Dissertação (Mestrado em Sociologia). Instituto de Economia, Universidade Estadual de Campinas.

GOLDENSTEIN, L. 1994. Repensando a dependência. Rio de Janeiro : Paz e Terra.

GONÇALVES, R. 1999. Globalização e desnacionalização. Rio de Janeiro : Paz e Terra.

HIRATA, H. (org.) 1993. Sobre o “modelo" japonês : automatização, novas formas de organização e de relações do trabalho. São Paulo : Edusp.

IBGE. 2001a. Anuário estatístico do Brasil. Rio de Janeiro : Instituto Brasileiro de Geografia e Estatística.

2001b. Pesquisa mensal de emprego. Rio de Janeiro : Instituto Brasileiro de Geografia e Estatística.

LIPIETZ, A. 1988. Miragens e milagres : problemas da industrialização no Terceiro Mundo. São Paulo : Nobel.

MALAGUTI, M. L. 2001. Crítica à razão informal : a imaterialidade do salariato. São Paulo : Boitempo.

MARTINS, H. S. \& RAMALHO, J. R. 1994. Diversidade e negociação no mundo do trabalho. São Paulo : Hucitec.

PESSANHA, E. G. F. \& MOREL, R. L. M. 1999. Mudanças recentes no modelo de relações de trabalho no Brasil e novo sindicalismo. In : RODRIGUES, I. (org.). O novo sindicalismo : vinte anos depois. Petrópolis : Vozes.

PESSOA, E. 1999. O emprego público sob a ótica dos serviços públicos : observações sobre a estrutura das ocupações em 1985, 1989 e 1995. Artigo apresentado no VI Encontro Nacional da Associação Brasileira de Estudos do Trabalho, realizado em Belo Horizonte.

POCHMANN, M. 1999. O trabalho sob fogo cruzado : exclusão, desemprego e precarização no final do século. São Paulo : Contexto.

2000a. A batalha pelo primeiro emprego. São Paulo : Publisher.

2000b. Mudanças (para pior) no mercado de trabalho. Gazeta Mercantil, São Paulo, 15.ago.

2001. O emprego na globalização : a nova divisão internacional do trabalho e os caminhos que o Brasil escolheu. São Paulo : Boitempo.

RODRIGUES, I. (org.). 1999. O novo sindicalismo : vinte anos depois. Petrópolis : Vozes.

. 1997. Sindicalismo, emprego e relações de trabalho na indústria automobilística. In : ANTUNES, R., BEYNON, H, MCILROY, J., RAMALHO, J. R. \& RODRIGUES, I. Neoliberalismo, trabalho e sindicatos : reestru- 
turação produtiva no Brasil e na Inglaterra. São Paulo : Boitempo.

SCHAFF, A. 1990. A sociedade informática : as conseqüências sociais da Segunda Revolução Industrial. São Paulo : UNESP.

SENNET, R. 1998. A corrosão do caráter. Rio de Janeiro : Record.

SILVA, J. G. 1999. O novo rural brasileiro.
Campinas : Instituto de Economia da Universidade Estadual de Campinas.

TOLEDO, J. R. \& ALENCAR, K. 2000. Exclusão social aumenta na década de 90. Folha de São Paulo, p. C1, 24.set.

VIANA, M. T. 1999. A proteção social do trabalhador no mundo globalizado : o direito do trabalho no limiar do Século XXI. Belo Horizonte : s/n.

\section{OUTRAS FONTES}

A adolescência prolongada. Gazeta Mercantil, São Paulo, 23.ago.2000.

A deterioração do emprego formal. Gazeta Mercantil, São Paulo, 28.maio.2001.

Capitais perdem mais empregos com crises. Folha de S. Paulo, 09.ago.2000.

Emprego público resiste à onda neoliberal. Gazeta Mercantil, São Paulo, 24.jul.2000.

Empregos aparecem, mas salários caem. Folha de S. Paulo, 24.ago.2000.

Fábricas brasileiras estão entre as mais modernas. O Estado de S. Paulo, 23.jul.2001.

Indústria brasileira produz mais sem contratar, Gazeta Mercantil, São Paulo, 22.nov.2000.

Mapa da inclusão/exclusão social 2000. São Paulo : Polis - Instituto de Estudos, Formação e Assessoria em Políticas Sociais.

Menos emprego, mais trabalho. $O$ Estado de $S$.
Paulo, Editorial, 09.jul.2000.

Mercado formal também segrega mulher. Folha de S. Paulo, 09.jul.2000.

Múltis crescem $146 \%$ na década liberal. Folha de S. Paulo, 10.fev.2002.

Renda cresce e desigualdade persiste. Gazeta Mercantil, São Paulo, 05.abr.2001.

Rodízio de trabalhadores achata renda. Folha de S. Paulo, 16.dez.2001

Sistema exclui $60 \%$ dos trabalhadores privados. O Estado de S. Paulo, 10.jun.2000.

Tecnologia produz indústria "sem fábrica". Folha de S. Paulo, 24.dez.2000.

Uma nação sem consumidores. CartaCapital, São Paulo, ano IX, n. 183, p. 10-14, 03.abr.2002.

Volkswagem terceiriza a logística da fábrica. Gazeta Mercantil, São Paulo, 16.abr.2001. 
investment that has been made in the automobile industry in the Greater Curitiba, state of Paraná. The research adopts a perspective on globalization that takes into account both global structures and mechanisms as well as the decision-making sphere of local government. The authors come to the conclusion that researchers should include social as well as political aspects in their analyses, as well as research the investments, strategies and operations of transnational firms in Brazil, employing interdisciplinary approaches that take international economic policy into account.

KEYWORDS: globalization, transnational enterprise, automobile industry.

$* * *$

\section{LABOR AND UNIONISM IN BRAZIL: A CRITICAL INVENTORY OF THE "NEOLIBERAL DECADE" (1990-2000)}

Giovanni Alves (Universidade Estadual Paulista - Marília)

This article presents an overview of principal shapes that the world of labor took on in Brazil during the nineties. We refer to this period as the "neo-liberal decade". We emphasize the development of a new complex of productive restructuring and its dominant moment (Toyotism), as well as the emergence of a new (and precarious) world of labor and the advent of the crisis of unionism, which we consider to be the contingent expression of the fragmentation of the working class. We come to the conclusion that today more than ever, at the start of the twenty first century, the greatest challenge that Brazilian unionism faces involves a break with its bureaucratic-corporative bias, as well as the organization and mobilization of a massive contingent of young workers and employees and even the precarious self-employed or workers subject to capitalist exploitation. We make critical use of empirical data from books and essays written by researchers from the fields of economics, sociology of work and industrial sociology in Brazil over the last decade

KEYWORDS: labor; unionism; Neo-liberalism; Toyotism, unemployment.

$* * *$

PIERRE BOURDIEU'S SOCIOLOGICAL LEGACY: TWO DIMENSIONS AND A PERSONAL NOTE

Loïc J. D. Wacquant (University of California, Berkeley/Centre de sociologie européene du Collège de France)

This article is made up of three parts, each of which re-traces and discusses the life and sociological work of Pierre Bourdieu, who died in January of 2002. The first section discusses the French thinker's career, and seeks to relate each stage of his life with the ongoing development of his thought - from his primary schooling in the French interior to his international recognition, and including his studies in Philosophy in Paris and anthropological research in Algeria. The second section uses an interview to engage in a discussion of reflexive sociology, of "the logic of practice", and of other concepts that Bourdieu formulated for the study of social reality and to incite the discovery of new research agendas. The third section discusses the importance of the journal Actes de la recherche en sciences sociales which Bourdieu founded, meant to transcend the several boundaries of nationality and disciplines which circumscribe and limit scientific production.

KEYWORDS: Pierre Bourdieu; intellectual trajectory; reflexive sociology; the logics of practice; Actes de la recherche en sciences sociales.

$* \quad * *$

EXPLAINING THE MANAGEMENT STATE'S IMPLEMENTATION CRISIS: PERFORMANCE VERSUS FISCAL ADJUSTMENT

Flávio da Cunha Rezende (Universidade Federal de Pernambuco) 
Cet article présente les résultats préliminaires d'une recherche dont l'objectif est de développer une référence théorique afin d'analyser les antécédents et les implications de la globalisation économique au Brésil. Plus particulièrement, l'article met en relief les problèmes de gouvernement et maintien environnemental concernant les investissements directs étrangers qui ont été effectués dans l'industrie automobile de la région de Curitiba, dans l'état du Paraná. La recherche suit une perspective particulière de globalisation qui considère autant les mécanismes et structures globales que l'espace de décision des gouvernements locaux. Les auteurs considèrent finalement que les chercheurs doivent prendre en compte non seulement les aspects sociaux mais encore les aspects politiques dans leurs analyses et qu'il faut entreprendre, lorsqu'on mène des recherches portant sur investissements, stratégies et opérations des entreprises transnationales, des approches interdisciplinaires compte tenu de l'approche du domaine de l'économie politique internationale.

MOTS-CLÉS: globalisation; entreprise transnationale; industrie automobile.

\section{TRAVAIL ET SYNDICALISME AU BRESIL: UN BILAN CRITIQUE “DES ANNÉES NEO- LIBERALES" (1990-2000)}

Giovanni Alves (Universidade Estadual Paulista - Marília)

Cet article présente un tableau des principaux contours du monde du travail au Brésil, dans les années 90. On appelle cette période "les années néo-libérales". On souligne le développement d'un nouveau réseau de restructuration productive et son moment le plus important (le toyotisme), la naissance d'un nouveau (et fragile) monde du travail et l'avènement de la crise du syndicalisme, considérée comme l'expression nécessaire de la fragmentation de la classe ouvrière. On estime qu'aujourd'hui, plus que jamais, le grand défi du syndicalisme au Brésil à l'aube du XXI ${ }^{\text {ème }}$ siècle est de rompre avec la tendance burocratique-corporatiste, d'organiser et de mobiliser un contigent important de jeunes ouvriers et ouvrières, employés, y compris les travailleurs indépendants en situation difficile et exploités par le capital. On a utilisé, dans une perspective critique, les données empiriques des livres et des essais de chercheurs du domaine de l'économie et de la sociologie de l'industrie et du travail au Brésil, parus tout au long des années 90.

MOTS-CLÉS: travail; syndicalisme; néo-libéralisme; toyotisme; chômage.

\section{L'HERITAGE SOCIOLOGIQUE DE PIERRE BOURDIEU: DEUX DIMENSIONS ET UNE TOUCHE PERSONNELLE}

Loïc J. D. Wacquant (University of Californie, Berkeley/Centre de socilogie europénne du Collège de France)

Cet article est composé de trois parties où l'on retrace la vie et l'oeuvre sociologique de Pierre Bourdieu, décédé en janvier 2002 et l'on en discute. La première partie présente la carrière du penseur français et cherche à mettre en rapport chaque étape de sa vie avec le développement de sa pensée depuis les premières études en province jusqu'à sa renommée internationale. On se reporte également à ses études de philosophie à Paris et aux investigations anthropologiques en Argélie. La seconde partie consiste en un débat, par le biais d'une interview, de la sociologie réflexive, de la "logique de la pratique" et d'autres concepts formulés par Bourdieu avec l'objectif d'étudier la réalité sociale et d'inciter à la découverte des nouveaux agendas de recherche. La troisième partie a pour thème l'importance de la revue Actes de la recherche en sciences sociales, fondée par le sociologue et destinée à dépasser les diverses frontières de nationalité et de disciplines, qui entourent et limitent la production scientifique.

MOTS-CLES: Pierre Bourdieu; trajectoire intellectuelle; sociologie réflexive; logique de la pratique; 